\title{
In-frame fusion of SUMO1 enhances ßarrestin2's association with activated GPCRs as well as with nuclear pore complexes
}

\author{
Karim Nagi ${ }^{\mathrm{a}, \mathrm{b}, 1}$, Suneet Kaur ${ }^{\mathrm{a}, 1}$, Yushi Bai ${ }^{\mathrm{a}}$, Sudha K. Shenoy ${ }^{\mathrm{a}, \mathrm{c}, *}$ \\ ${ }^{a}$ Department of Medicine, Division of Cardiology, Duke University Medical Center, Durham, NC 27710, USA \\ ${ }^{\mathrm{b}}$ College of Medicine, QU Health, Qatar University, Doha, Qatar \\ c Department of Cell Biology, Duke University Medical Center, Durham, NC 27710, USA
}

\section{A R T I C L E I N F O}

\section{Keywords:}

Beta-arrestin

BRET

RanGAP1

SUMO

Ubiquitin

$\mathrm{G}$ protein-coupled receptor

\begin{abstract}
A B S T R A C T
Small ubiquitin like modifier (SUMO) conjugation or SUMOylation of ßarrestin2 promotes its association with the clathrin adaptor protein AP2 and facilitates rapid $\beta_{2}$ adrenergic receptor $\left(\beta_{2} \mathrm{AR}\right)$ internalization. However, disruption of the consensus SUMOylation site in $\beta$ arrestin2, did not prevent $\beta$ arrestin2's association with activated $\beta_{2} A R s$, dopamine $D_{2}$ receptors $\left(D_{2} R s\right)$, angiotensin type 1a receptors $\left(A T_{1 a} R s\right)$ and $V_{2}$ vasopressin receptors $\left(\mathrm{V}_{2} \mathrm{Rs}\right)$. To address the role of SUMOylation in the trafficking of ßarrestin and GPCR complexes, we generated and characterized a yellow fluorescent protein (YFP) tagged ßarrestin2-SUMO1 chimeric protein, which is resistant to de-SUMOylation. In HEK-293 cells, YFP-SUMO1 predominantly localized in the nucleus, whereas YFPßarrestin2 is cytoplasmic. YFP-ßarrestin2-SUMO1 in addition to being cytoplasmic, is localized at the nuclear membrane. Nonetheless, $\beta$ arrestin2-SUMO1 associated robustly with agonist-activated $\beta_{2} A R s$ as evaluated by co-immunoprecipitation, confocal microscopy and bioluminescence resonance energy transfer (BRET). ßarrestin2-SUMO1 associated strongly with the $\mathrm{D}_{2} \mathrm{R}$, which forms transient complexes with $\beta$ arrestin2. But, ßarrestin2-SUMO1 and ßarrestin2 showed equivalent binding with the $V_{2} R$, which forms stable complexes with ßarrestin2. ßarrestin2 expression level directly correlated with the steady state levels of the unmodified form of RanGAP1, which upon SUMOylation associates with nuclear membrane. On the other hand, Barrestin2-SUMO1 not only localized at the nuclear membrane, but also formed a macromolecular complex with RanGAP1. Taken together, our data suggest that SUMOylation of ßarrestin2 promotes its protein interactions at both cell and nuclear membranes. Furthermore, ßarrestin2-SUMO1 presents as a useful tool to characterize $\beta$ arrestin2 recruitment to GPCRs, which form transient and unstable complex with ßarrestin2.
\end{abstract}

\section{Introduction}

ßarrestin2 (also called Arrestin3) is an adaptor protein that regulates signal transduction and trafficking of the seven-transmembrane G protein-coupled receptors (GPCRs) [1-4]. ßarrestin1 and ßarrestin2 are highly conserved mammalian proteins, which display high affinity interaction with agonist-activated GPCRs that are phosphorylated on specific serine/threonine residues by GPCR kinases (GRKs) [1]. ßarrestins and GRKs uncouple the agonist-activated GPCRs from cognate heterotrimeric $\mathrm{G}$ proteins blocking $\mathrm{G}$ protein and second messengerdependent signaling. Barrestins in turn provoke GPCR endocytosis and additionally scaffold kinases resulting in ßarrestin-dependent signal transduction [1,5]. In addition to GPCRs, ßarrestins can bind other types of cell-surface receptors, ion channels, and engage many signaling and biochemical pathways [6].
Barrestin2 is a cytoplasmic protein, whose activity is regulated by not only GPCR recruitment, but also by phosphorylation [7,8], ubiquitination $[9,10]$, and nitrosylation [11,12]. GPCR activation triggers ubiquitination of lysine residues in ßarrestin2 and the sites of ubiquitination as well as the kinetics and patterns of ubiquitination have distinct correlation to particular GPCR:ßarrestin complexes [9,13]. For example, activation of the angiotensin $\mathrm{AT}_{1 \mathrm{a}}$ receptor $\left(\mathrm{AT}_{1 \mathrm{a}} \mathrm{R}\right)$ induces ubiquitination at lysines 11 and 12 in Barrestin2, which is critical for the formation of $\mathrm{AT}_{1 \mathrm{a}} \mathrm{R}$ : $\beta$ arrestin2 signalosomes [14]. Ubiquitinated ßarrestin2 possesses greater binding affinity than non-ubiquitinated ßarrestin2 with (a) activated GPCRs, (b) clathrin subunits and (c) components of ERK signaling (c-Raf and ERK), which suggests a tight relationship between $\beta$ arrestin ubiquitination status, endocytosis and the transmission of ßarrestin-dependent signaling [9].

ßarrestin2 is also regulated by covalent modification by SUMO

\footnotetext{
* Corresponding author at: Duke University Medical Center, Rm 148A, CARL Bldg. PO Box 102146; 213, Research drive, Durham, NC-27710.

E-mail address: skshenoy@dm.duke.edu (S.K. Shenoy).

${ }^{1}$ These authors contributed equally.
} 
(small ubiquitin like modifier) or SUMOylation [15,16]. Ubiquitin and SUMO share little sequence identity, but adapt similar structural conformation, and both require a three step enzyme cascade for substrate modification [17]. SUMOylation is generally targeted to a canonical protein sequence ( $\Psi$-K-X-D/E), where $\Psi$ is an aliphatic amino acid, $\mathrm{K}$ is the target site for the covalent modification by SUMO, $\mathrm{X}$ is any amino acid and is followed by an acidic residue [17-21]. Additionally, SUMOylation and ubiquitination are dynamic and reversed by cognate deSUMOylases and de-ubiquitinases, respectively.

SUMOylation of lysine- 400 on bovine ßarrestin2 is critical for the interaction of ßarrestin2 and the endocytic adaptor protein2 (AP2), but not for the translocation of $\beta$ arrestin2 to activated $\beta_{2} A R$ and $A_{1 a} R$ [15]. The consensus motif containing lysine- 400 in bovine $\beta$ arrestin2 is not conserved in ßarrestin homologs; for human ßarrestin2, lysine-295 was shown to be the critical site for SUMOylation, which attenuated the ability of ßarrestin2 to inhibit TRAF6 dimerization and downstream $\mathrm{NF \kappa B}$ activation triggered by IL-1R [16]. Interestingly, human $\beta a r-$ restin2 SUMOylation is dynamically reversed by the deSUMOylase SUMO specific protease 1 (SENP1) [16]. There is little information on how SUMOylation affects ßarrestin2 trafficking, an inherent property of activated ßarrestins, which transpires independent of $G$ proteins [22]. To ascertain the functional effects of SUMOylation of ßarrestin2, we generated a ßarrestin2-SUMO1 chimera, which is not targeted by deSUMOylases and would be persistently SUMOylated. We tested $\beta$ arrestin-SUMO1 for its binding to different GPCRs with low and high affinities for ßarrestin2 association. We also unexpectedly discovered that SUMOylated ßarrestin2 is associated with the nuclear membrane and forms a macromolecular complex with the nuclear membrane protein RAs-related Nuclear protein GTPase Activating Protein 1 (RanGAP1), suggesting novel functions for SUMOylated ßarrestin2.

\section{Materials and methods}

\subsection{Materials}

The antibodies used for our studies include: anti-FLAG M2 (Sigma: F3165), anti-HA 12CA5 (Roche: 11666606001), anti- $\beta_{2}$ AR H20 (Santa Cruz: sc-569), anti-GAPDH-HRP (Cell Signaling: 3683), and anti-GFP/ GFP-variants (MBL International Corporation: \#598). Alexa 594 conjugated secondary antibody was obtained from Invitrogen. For immunoprecipitation of YFP-fusion proteins, we used GFP Monoclonal Antibody (3E6), A-11120, from Thermo Fisher Scientific. Horseradish peroxidase-conjugated secondary antibodies were from GE/Amersham or Rockland Immunochemicals. Anti-FLAG M2 affinity gel (Sigma: A2220), Protein G Plus/Protein A-Agarose (Calbiochem: IP10), (-)-Isoproterenol (Sigma: I2760), Dopamine (Sigma: H8502), Angiotensin II (Sigma: A9525), Arginine vasopressin (Sigma: V9879), N-Ethylmaleimide (Sigma: E1271), Triton X-100 (Sigma: T-9284), Pierce $^{\mathrm{TM}}$ anti-HA magnetic beads (Thermo Fisher Scientific: 88837) and, DSP (dithiobis(succinimidyl propionate)) (Thermo Fisher Scientific: 22585). Lipofectamine 2000 was from Invitrogen.

The plasmid constructs, pcDNA3/mYFP-ßarrestin2-K296R, pcDNA3/mYFP-ßarrestin2-SUMO1, and pCDNA3-FLAG-ßarrestin2SUMO1 were generated by standard cloning and/or mutagenesis protocols. The plasmid constructs, pcDNA3/mYFP-ßarrestin2 and pcDNA3/mYFP-ßarrestin2-ubiquitin have been reported before [23]. $\beta_{2}$ AR-Rluc, was generously provided by Dr. Lefkowitz. $V_{2} R$-RlucII was kindly provided by Dr. Michel Bouvier and $H A-V_{2} R, H A-D_{2} R$, and $D_{2} R-$ RlucII were kindly provided by Dr. Marc Caron. YFP-SUMO1 plasmid was purchased from Addgene (\#13380) [24].

\subsection{Cell culture and transfection}

HEK-293 cells purchased from American Type Culture Collection (Manassas, VA) maintained in MEM medium containing $10 \%$ fetal bovine serum and $100 \mu \mathrm{g} / \mathrm{mL}$ penicillin/streptomycin at $37^{\circ} \mathrm{C}$ in a humidified incubator at $5 \% \mathrm{CO}_{2}$. Transfections were performed using Lipofectamine 2000 reagent (Invitrogen). HEK-293 cells stably transfected with FLAG- $\beta_{2} A R$, used in these studies have been described

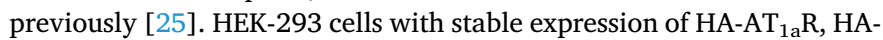
$\mathrm{D}_{2} \mathrm{R}$, or $\mathrm{HA}-\mathrm{V}_{2} \mathrm{R}$ were generated by standard procedures using antibiotic selection as reported before [22].

Human embryonic kidney 293 T (HEK-293 T) cells were cultured in Dulbecco's modified Eagle's medium (DMEM) supplemented with $4.5 \mathrm{~g} /$ L glucose, $10 \%$ fetal bovine serum and 1\% Antibiotic-Antimycotic (Gibco) at $37{ }^{\circ} \mathrm{C}$ in a humidified atmosphere at $95 \%$ air and $5 \% \mathrm{CO}_{2}$. For transient expression of recombinant proteins, HEK-293 T cells were seeded at a density of $6 \times 10^{5}$ cells in $35 \mathrm{~mm}$ cell culture dishes such that they reach $40-50 \%$ confluence on the next day. Cells were then cultured for $24 \mathrm{~h}$ and transfected with vectors encoding BRET constructs as detailed below using calcium phosphate according to a previously published protocol [26]. HEK-293 T cells are the preferred model system for BRET assays because of their high transfection efficiency of GPCR-Rluc constructs.

\subsection{BRET assays}

For assessing ßarrestin2 recruitment to receptors, bioluminescence resonance energy transfer (BRET) assays were performed in HEK-293 T cells. We first completed titration assays which allowed to determine the specificity of association among different interaction partners [26-30]. To achieve this, a fixed amount of the donor-tagged (Renilla luciferase, Rluc) construct was co-transfected with increasing amounts of the corresponding interaction partner bearing the acceptor (YFP). Donor-acceptor DNA ratios corresponding to the beginning of the saturation plateau were subsequently used for single-point and dose-response assays [31,32]. Two days after transfection, HEK-293 T cells expressing different BRET pairs were washed with serum-free clear MEM media (Gibco) and exposed to vehicle or stimulated for the indicated times at $37^{\circ} \mathrm{C}$. BRET readings were acquired using Synergy Neo2S plate reader (BioTek Instruments Inc.) and obtained 5 min after manual addition of Rluc substrate, coelenterazine $h$ (Promega) to a final concentration of $5 \mu \mathrm{M}$.

The BRET signal generated was determined by calculating the ratio of light emitted by YFP (520-550 nm) over the light emitted by Rluc $(440-480 \mathrm{~nm})$. These values were then corrected by subtracting the background signal (detected when the Rluc-tagged construct was expressed without acceptor) from the BRET signal detected in cells coexpressing both donor and acceptor constructs. Agonist-induced BRET values were calculated by subtracting net BRET values of non-stimulated conditions from net BRET values corresponding to the stimulated conditions.

\subsection{Immunostaining and confocal microscopy}

In experiments assessing $\beta$ arrestin2 recruitment to receptors, HEK293 stably expressing FLAG- $\beta_{2} A R, H A-D_{2} R, H A-V_{2} R$, or HA-AT ${ }_{1 a}$ R were seeded on poly lysine-coated 35-mm glass bottom plates at a density of 100,000 cells per dish. On the following day, cells were transiently transfected with $500 \mathrm{ng}$ of YFP-tagged constructs (YFP-ßarrestin2-WT, YFP-ßarrestin2-K296R, YFP-ßarrestin2-SUMO1, YFP-ßarrestin2-Ub, or YFP-SUMO1) using Lipofectamine 2000 (Invitrogen). Twenty-four hours post-transfection, cells were serum-starved for $4 \mathrm{~h}$, and either left untreated or treated with respective agonists for the indicated times in the figure legends. After stimulation, cells were fixed with $5 \%$ formaldehyde diluted in phosphate-buffered saline (PBS), permeabilized with $0.1 \%$ Triton $\mathrm{X}-100$ in PBS containing $2 \%$ bovine serum albumin (BSA) for $20 \mathrm{~min}$ and subsequently incubated overnight at $4{ }^{\circ} \mathrm{C}$ with appropriate primary antibody diluted in PBS containing $2 \%$ BSA with no Triton X-100. The next day, cells were washed three times with PBS and incubated with Alexa594 conjugated secondary antibody for $1 \mathrm{~h}$, followed by repeated washes using PBS. Confocal images were acquired 
A

\begin{tabular}{|lll|}
\hline Rat & $\beta$-arr2 & ${ }^{291}$ LDGQLKHEDTNL \\
Mouse & $\beta$-arr2 & ${ }^{291}$ LDGQLKHEDTNL \\
Human & $\beta$-arr2 & ${ }^{290} \mathrm{LDGQ}$ LKHEDTNL \\
Bovine & $\beta$-arr2 & ${ }^{290}$ LDGQLKHEDTNL \\
\hline
\end{tabular}
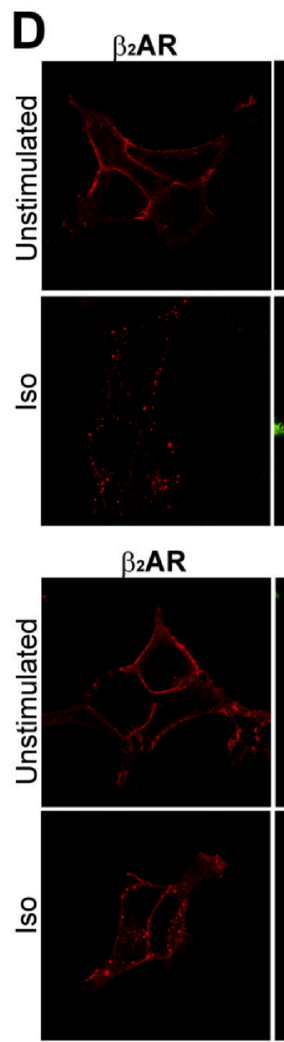

B

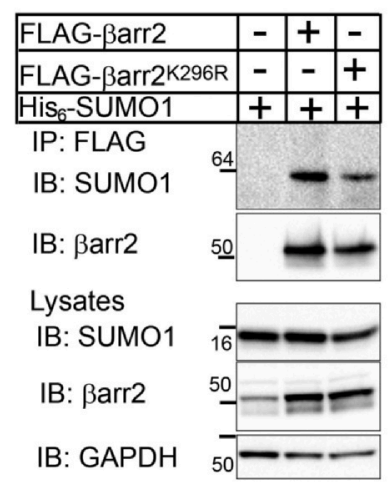

C

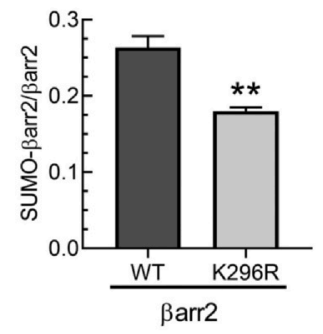

E
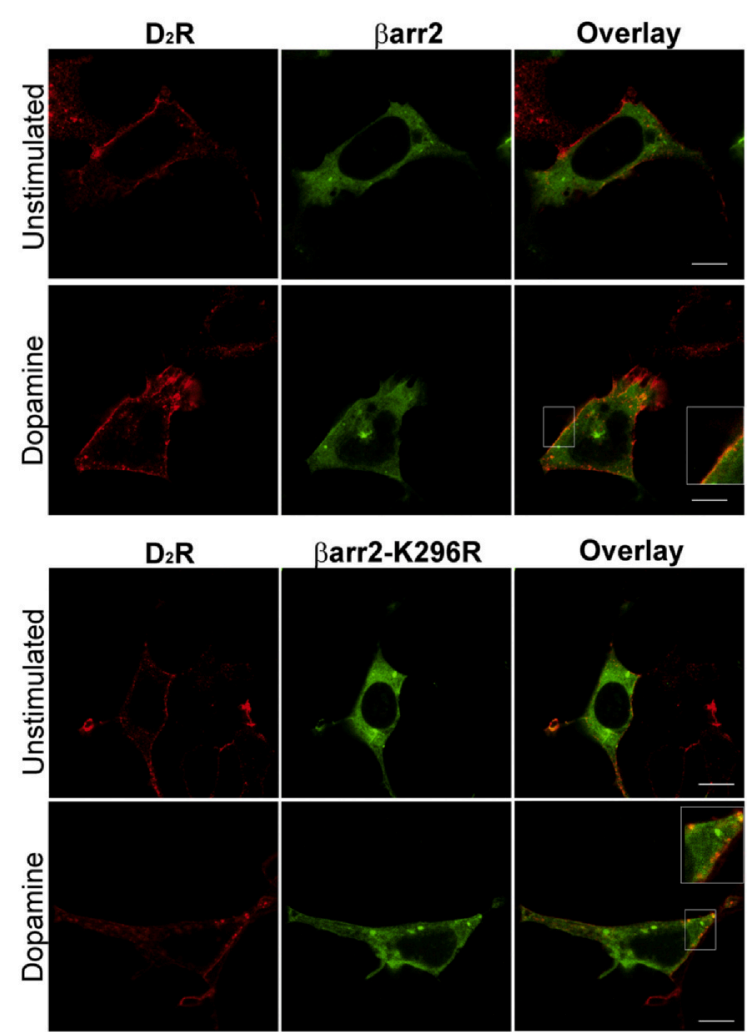

Overlay

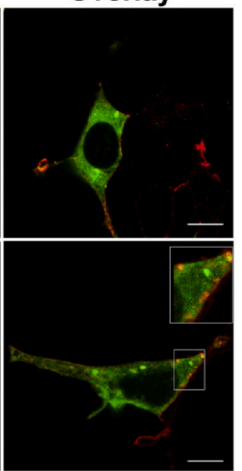

Fig. 1. SUMOylation at the canonical site in ßarrestin2 is not required for association with agonist-activated GPCRs.

(A) SUMOylation consensus motif ( $\psi \mathrm{KXE}$ or LKHE) shown in the sequence alignment of rat, mouse, human and bovine $\beta$ arrestin2. Lysine 295/296 shown is a conserved site for SUMOylation. (B) HEK-293 cells were transfected with vector, FLAG- $\beta$ arrestin2 or FLAG $\beta$ arrestin2-K296R along with His ${ }_{6}$-SUMO1. FLAG immunoprecipitates were serially probed for $\mathrm{His}_{6}{ }_{-}$SUMO1 and ßarrestin2. Lysates were analyzed for SUMO1, $\beta$ arrestin2 and GAPDH as shown. (C) The bar graphs show the means \pm SEM for the ratios obtained by dividing SUMO1 bands by the cognate $\beta$ arrestin2 bands detected in the IP samples in panel B and the data is summarized from three independent experiments. ${ }^{* *} p=0.006$ versus WT, unpaired $t$-test. (D) HEK-293 cells stably transfected with FLAG- $\beta_{2}$ AR and either $\beta$ arrestin2 or ßarrestin2-K296R were treated \pm agonist isoproterenol (Iso, $1 \mu \mathrm{M}$ ) for $5 \mathrm{~min}$, and cells were processed by immunostaining as described in "Methods" to visualize subcellular distribution of the $\beta_{2} \mathrm{AR}$ (in red channel) and YFP-ßarrestin constructs (in green channel) by confocal microscopy. (E) Subcellular distributions of ßarrestin2 WT and K296R were determined as described for panel (D) except that cells expressed HA- $\mathrm{D}_{2} \mathrm{R}$ and treated \pm dopamine (10 $\left.\mu \mathrm{M}\right)$. In panels D and E representative images shown are from one of three independent experiments. For $\mathrm{D}$ and $\mathrm{E}$, a portion of the overlay image of Iso or dopamine- treated cells is enlarged to visualize the translocation of YFP-ßarrestin2 constructs. Scale Bar $=10 \mu \mathrm{m}$. (For interpretation of the references to colour in this figure legend, the reader is referred to the web version of this article.)

using Zeiss LSM 510 laser-scanning microscope using multitrack sequential with excitation (488 and $568 \mathrm{~nm}$ ) and emission (BP $505-550 \mathrm{~nm}$ and LP $585 \mathrm{~nm})$ filter sets. Images $(1024 \times 1024$ pixels $)$ were collected using either a $63 \times$ or $100 \mathrm{x}$ oil immersion lens. Images were processed for figure presentation using Adobe Photoshop software, and any increase or decrease of brightness/contrast was applied to the entire image. The nuclear rim localization of YFP-ßarrestin2SUMO1 is readily visualized in cells with low to moderate expression of YFP-protein. In cells with high expression, this localization is present, and can be discerned by enlarging sections of the nuclear rim.

\subsection{Cross-linking, immunoprecipitation and immunoblotting}

HEK-293 cells stably expressing FLAG- $\beta_{2} A R$, HA- $D_{2} R$, or HA- $V_{2} R$ were transiently transfected with $2 \mu \mathrm{g}$ of YFP-ßarrestin2-WT or YFPßarrestin2-SUMO1 using Lipofectamine 2000 (Invitrogen). Twenty-four hours post-transfection, cells were starved in PBS containing $10 \mathrm{mM}$ HEPES ( $\mathrm{pH} 7.4$ ) for $1 \mathrm{~h}$ and stimulated with vehicle or agonist (isoproterenol, $1 \mu \mathrm{M}$; or AVP $0.1 \mu \mathrm{M}$, or Dopamine $10 \mu \mathrm{M}$ ) at $37^{\circ} \mathrm{C}$ for desired times. After agonist-stimulations, $\beta_{2} \mathrm{AR}$ stable cells were treated with the crosslinker DSP to a final concentration of $480 \mathrm{nM}$, and plates 
A

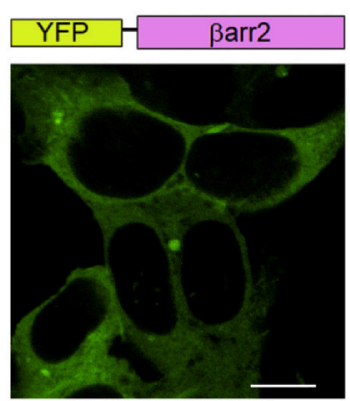

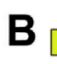

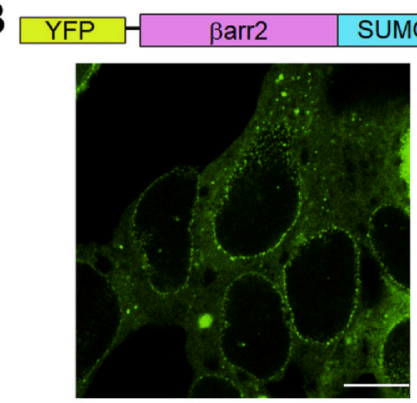

\section{C}

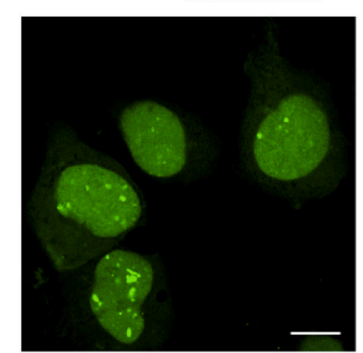

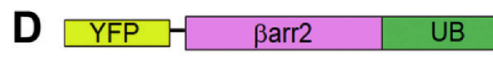

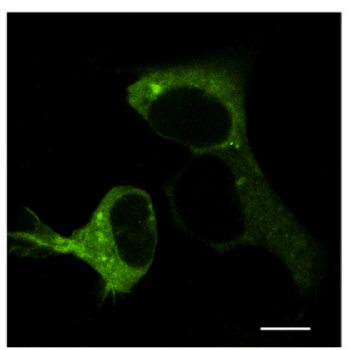

Fig. 2. Subcellular distribution of YFP tagged $\beta$ arrestin2, $\beta$ arrestin2-SUMO1 fusion, SUMO1 and $\beta$ arrestin2-Ub.

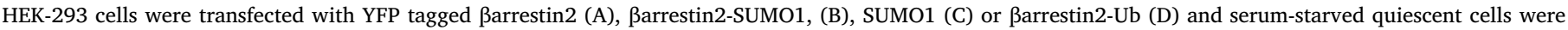
visualized using a confocal microscope. Representative images are shown from one of three independent experiments. Scale Bar $=10 \mu \mathrm{m}$.

were rocked for $20 \mathrm{~min}$ at room temperature. Reaction was quenched by adding $25 \mu \mathrm{L}$ of $1 \mathrm{M}$ Tris-Cl pH 8.5 per $1 \mathrm{~mL}$ volume of buffer in the dish and rocked for additional $5 \mathrm{~min}$ at room temperature. For the HA$\mathrm{D}_{2} \mathrm{R}$ and $\mathrm{HA}-\mathrm{V}_{2} \mathrm{R}$ samples, detection of protein association with ßarrestin2 did not require chemical crosslinking.

Harvested cells were washed with ice-cold PBS (pH 7.4) and solubilized in an ice-cold lysis buffer (50 mM HEPES (pH 7.5), 2 mM EDTA, $250 \mathrm{mM} \mathrm{NaCl}, 10 \%(\mathrm{v} / \mathrm{v})$ glycerol, and $0.5 \%(\mathrm{v} / \mathrm{v})$ IGEPAL CA-630) that was supplemented with phosphatase and protease inhibitors $(1 \mathrm{mM}$ sodium orthovanadate, $1 \mathrm{mM}$ sodium fluoride, $1 \mathrm{mM}$ phenylmethylsulfonyl fluoride, $5 \mu \mathrm{g} / \mathrm{mL}$ leupeptin, $5 \mu \mathrm{g} / \mathrm{mL}$ aprotinin, $1 \mu \mathrm{g} / \mathrm{mL}$ pepstatin $\mathrm{A}$, and $100 \mu \mathrm{M}$ benzamidine). Cell lysates were centrifuged at $13,000 \mathrm{rpm}$ for $20 \mathrm{~min}$ at $4{ }^{\circ} \mathrm{C}$ to remove cell debris and the supernatant containing solubilized membranes and cytosol was recovered. Cell lysate protein concentrations were determined by Bradford protein assay and equivalent $\mu \mathrm{g}$ of proteins were immunoprecipitated using anti-FLAG M2 antibody resin (for Fig. 4) or Anti-HA magnetic beads from Thermo Pierce (for Figs. 7 and 9). Samples were rotated overnight at $4^{\circ} \mathrm{C}$, then washed three times with lysis buffer to eliminate non-specific proteins and proteins bound to beads were eluted in SDS-PAGE sample buffer. Samples separated on SDSPAGE were transferred onto nitrocellulose membrane (Bio-Rad) and YFP-tagged $\beta$ arrestin2 fusion proteins associated with FLAG- $\beta_{2}$ AR, HA$\mathrm{D}_{2} \mathrm{R}$ or HA- $\mathrm{V}_{2} \mathrm{R}$ were revealed using anti-GFP antibody (MBL-598) and anti-rabbit secondary HRP-conjugated antibody (1:3000; GE Healthcare). FLAG- $\beta_{2}$ ARs in each sample were detected by probing membranes with anti- $\beta_{2} A R$ H-20 antibody (1:1000; Santa Cruz Biotechnology) and the corresponding secondary antibody (15,000; GE Healthcare). HA- $\mathrm{D}_{2} \mathrm{R}$ or $\mathrm{HA}-\mathrm{V}_{2} \mathrm{R}$ were detected using an anti-HA IgG (Cell Signaling Technologies). Chemiluminescence detection reagents (SuperSignal West Pico reagent, Pierce) were used to reveal the blotted proteins, and relative intensities of the labeled bands were detected by densitometric scanning using a charge-coupled device camera system (Bio-Rad Chemidoc-XRS) and quantified with Image-Lab software (BioRad).

\section{6. siRNA transfection and immunoblotting}

HEK-293 or HEK-293 T cells stably expressing the $\beta_{2} \mathrm{AR}$ were transfected with either non-targeting control siRNA or siRNA targeting ßarr2 purchased from Dharmacon GE Healthcare Life Sciences as described previously [5]. Early passage cells on 6-well dishes, at a confluence of $40-50 \%$ were transfected with $3.5 \mu \mathrm{g}$ siRNA using Lipofectamine $2000^{\mathrm{TM}}$ in serum-free media. After $4 \mathrm{~h}$, complete media was added to the transfected cells, and then grown for $48 \mathrm{~h}$ at $37^{\circ} \mathrm{C}$ before conducting assays. Cells were serum starved for $1 \mathrm{~h}$ prior to stimulation with $1 \mu \mathrm{M}$ isoproterenol for $20 \mathrm{~min}$. After stimulation, cells were solubilized by adding $2 \times$-SDS-sample buffer, followed by disruption by sonication. Equal amount of cell lysates were resolved on 10\% SDSpolyacrylamide gels (ProtoGel, National Diagnostics). RanGAP1, ßarrestins and GAPDH were detected by immunoblotting with rabbit monoclonal anti-RanGAP1antibody (Abcam ab92360, 1:1000), antißarrestin (A1CT, 1:3000) and rabbit monoclonal anti-GAPDH (HRP conjugate, CST 3683, 1:1000) respectively.

\section{Results}

3.1. Disruption of the consensus SUMOylation site in Barrestin2 does not alter its plasma membrane translocation and interaction with activated GPCRs

SUMOylation is targeted to a canonical protein sequence ( $\Psi-\mathrm{K}-\mathrm{X}-\mathrm{D}$ / E), where $\Psi$ is an aliphatic amino acid, $\mathrm{K}$ is the target site for the covalent modification by SUMO, $\mathrm{X}$ is any amino acid and is followed by an acidic residue [33]. A sequence alignment comparison of human, rat, mouse and bovine ßarrestin2 is shown in Fig. 1A displaying the canonical SUMOylation site, LKHE in ßarrestin2. Previous studies have shown that lysine-295 in bovine and human ßarrestin2 serves as a target site for SUMOylation and mutation of lysine-295 did not eliminate but significantly reduced SUMO conjugation of ßarrestin2 $[15,16]$. To test whether this is also true for rat $\beta$ arrestin2, we compared SUMOylation of rat ßarrestin2 and ßarrestin2-K296R overexpressed in HEK-293 cells along with His-SUMO1 (Fig. 1B-C). SUMOylation was significantly decreased but not eliminated in ßarrestin2K296R suggesting the possibility that lysines in ßarrestin2 that do not conform to the consensus motif may be targeted for SUMOylation.

We next tested if the site-specific SUMOylation at lysine 296 (Fig. 1A) impacts ßarrestin2 trafficking and localization in cells. We compared trafficking and association of ßarrestin2 and ßarrestin2K296R with activated $\beta_{2} A R, D_{2} R, A_{1 a} R$ and $V_{2} R$ in HEK-293 cells (Fig. 1D-E, and Fig. S1). With these GPCRs, we observed similar patterns of sub-cellular distribution of YFP-ßarrestin2 and YFP-ßarrestin2K296R in quiescent cells. Upon agonist activation, we observed transient plasma membrane translocation of both ßarrestin2 as well as ßarrestin2-K296R to the $\beta_{2} \mathrm{AR}$ and $\mathrm{D}_{2} \mathrm{R}$ (Fig. 1D-E). We also detected robust endosomal localization of $\mathrm{AT}_{1 \mathrm{a}} \mathrm{R}$ - $\beta$ arrestin2 and $\mathrm{V}_{2} \mathrm{R}$ - $\beta$ arrestin2 complexes, for both WT and K296R ßarrestins (Fig. S1A-B). Accordingly, we infer that the SUMOylation at the consensus motif in ßarrestin2 has negligible effect of the overall trafficking and GPCR affinity of ßarrestin2. In fact, to eliminate SUMOylation of bovine ßarrestin2, a total of four lysines had to be mutated, and only two of them were within a canonical SUMOylation motif. Nonetheless, the 4KR-arrestin3 mutant still translocated and associated with the activated $\beta_{2} \mathrm{ARs}$ at the plasma membrane [15]. Accordingly, either SUMOylation of lysine(s) in non-canonical sequence motif or ubiquitination of ßarrestin2, may overcome the defect produced by the disruption of SUMOylation at the canonical site. 
A
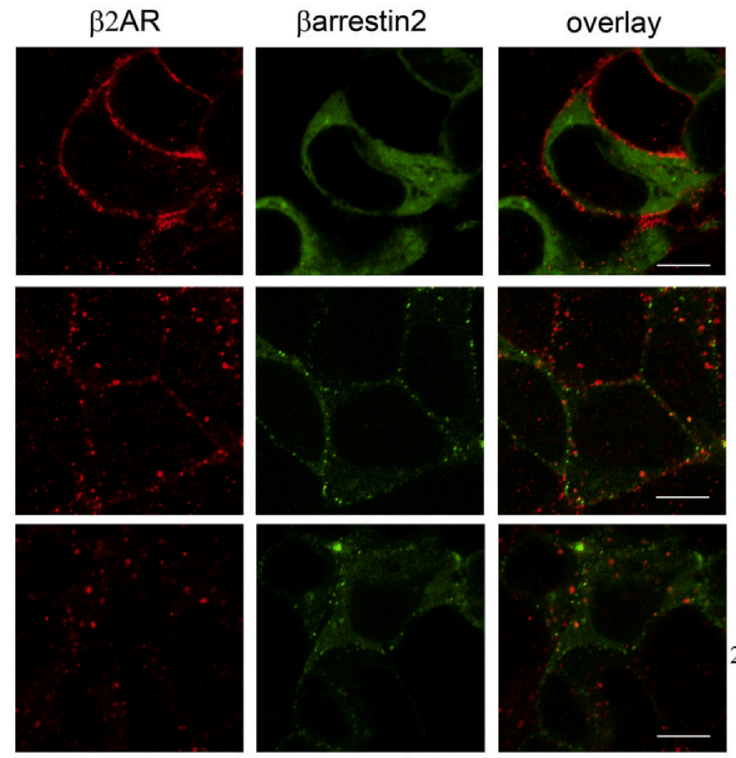

C
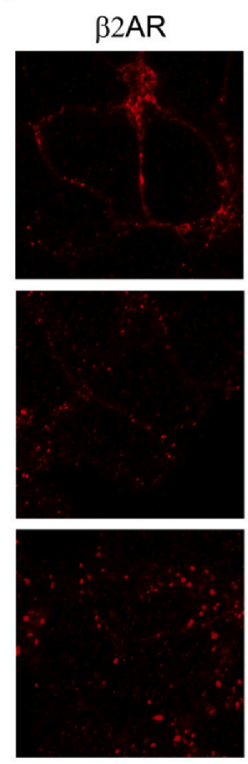

SUMO1
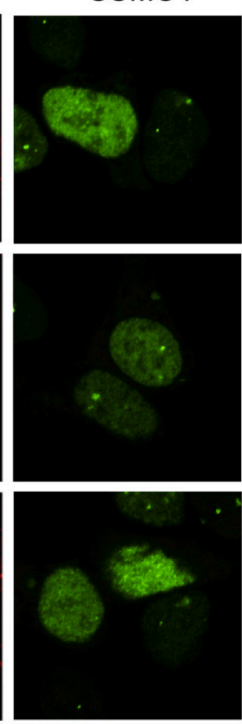

overlay
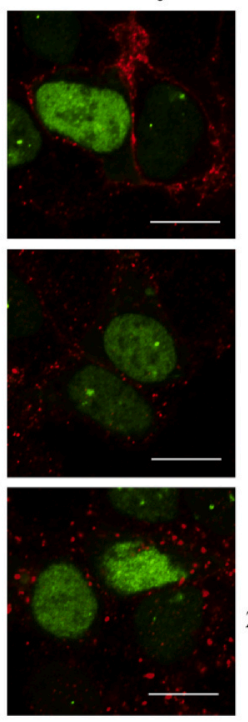

B
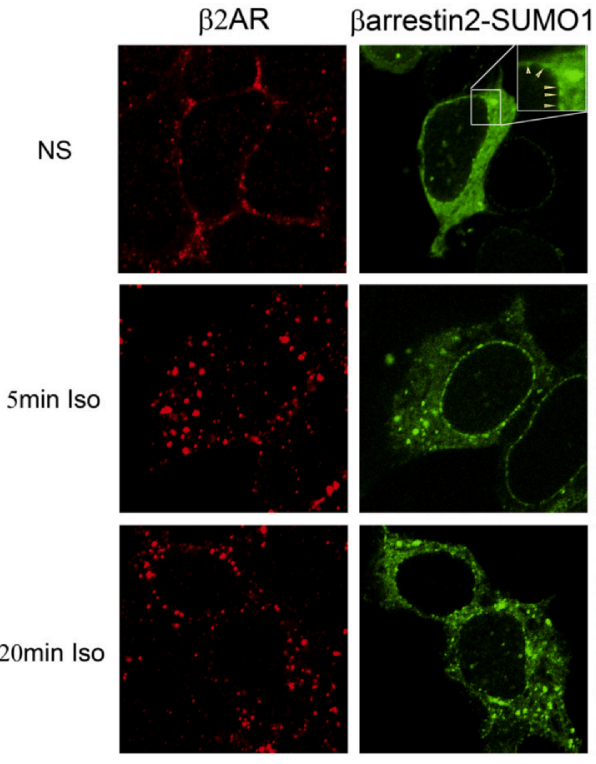

D

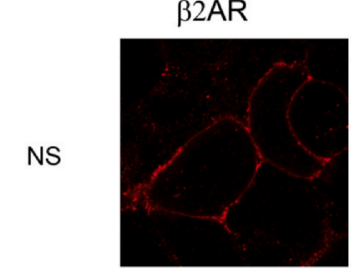

Barrestin2-Ub
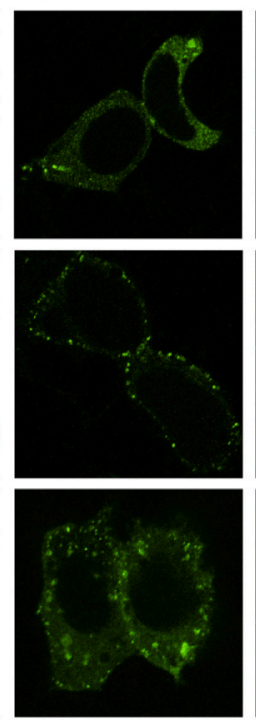

$5 \mathrm{~min}$ Iso
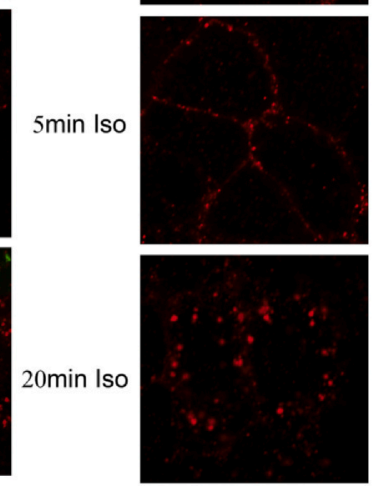

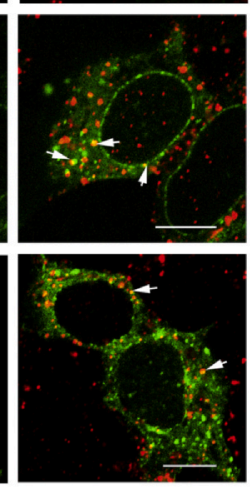

overlay

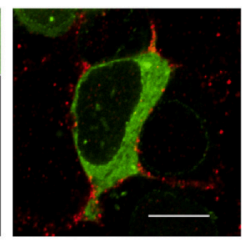

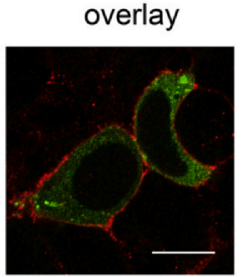
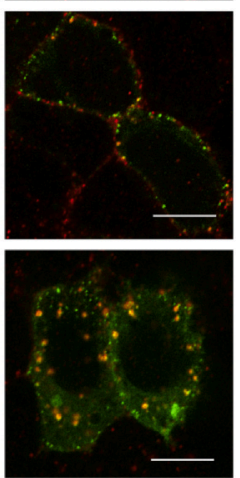

Fig. 3. Differential trafficking patterns of $\beta$ arrestin2, $\beta$ arrestin2-SUMO1, $\beta$ arrestin2-Ub proteins following $\beta_{2} A R$ stimulation.

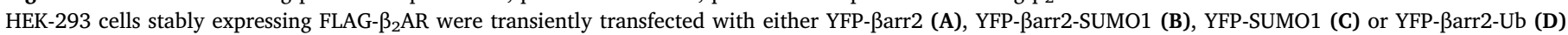
constructs. On the day of the experiment, cells were starved for $4 \mathrm{~h}$ in serum-free media and stimulated or not with isoproterenol (Iso, $1 \mu \mathrm{M})$ for the indicated times. Cells were then fixed and permeabilized before being immunostained with $\mathrm{H}-20$ antibody to label the $\beta_{2} \mathrm{AR}$. Confocal images show the receptor immunofluorescence (red) and the YFP fluorescence (green). Colocalization (yellow) of the receptor with respective ßarrestin2 fusion proteins is indicated in the overlay. Images shown are from one of three identical experiments. In panel B, a section of the image for unstimulated condition (green channel) is enlarged to visualize puncta around the nucleus, which is not conspicuous in bright cells. Scale Bar $=10 \mu \mathrm{m}$. (For interpretation of the references to colour in this figure legend, the reader is referred to the web version of this article.)

\subsection{Subcellular distribution of Barrestin2-SUMO1 chimera}

According to published studies, ßarrestin2 binds the de-SUMOylase SENP1 [16], and hence deducing the impact of SUMOylation on ßarrestin2 trafficking could be elusive due to the dynamic nature of the modification. To circumvent this issue, we generated a YFP tagged ßarrestin2-SUMO1 chimera, which would be resistant to the enzymatic activity of SENP1. YFP-ßarrestin2-SUMO1 expressed in the cytoplasm akin to YFP-ßarrestin2; but, we also detected ßarrestin2-SUMO1 at the nuclear membrane (Fig. 2A-B). YFP-SUMO1 was predominantly nuclear, and did not display the ring like distribution that we observed with ßarrestin2-SUMO1 (Fig. 2C). We analyzed the distribution of mYFP-ßarrestin2-SUMO1 (85 cells) versus mYFP-SUMO1 (80 cells), and found that while all cells expressing ßarrestin2-SUMO1 showed localization of YFP fluorescence at the nuclear membrane, none of the cells transfected with YFP-SUMO1 showed this pattern. Previous studies detected YFP-SUMO1 mostly in the nucleus and nucleolus, along with punctate pattern at the nuclear membrane in HeLa cells that were subjected to mitotic synchronization [24]; however, we did not observe distinct localization of YFP-SUMO1 at the nuclear membrane in HEK- 
A

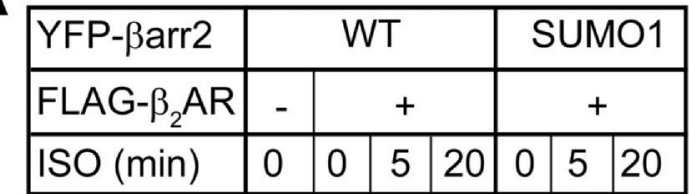

IP: FLAG

IB: YFP

$\beta_{2} A R$

64
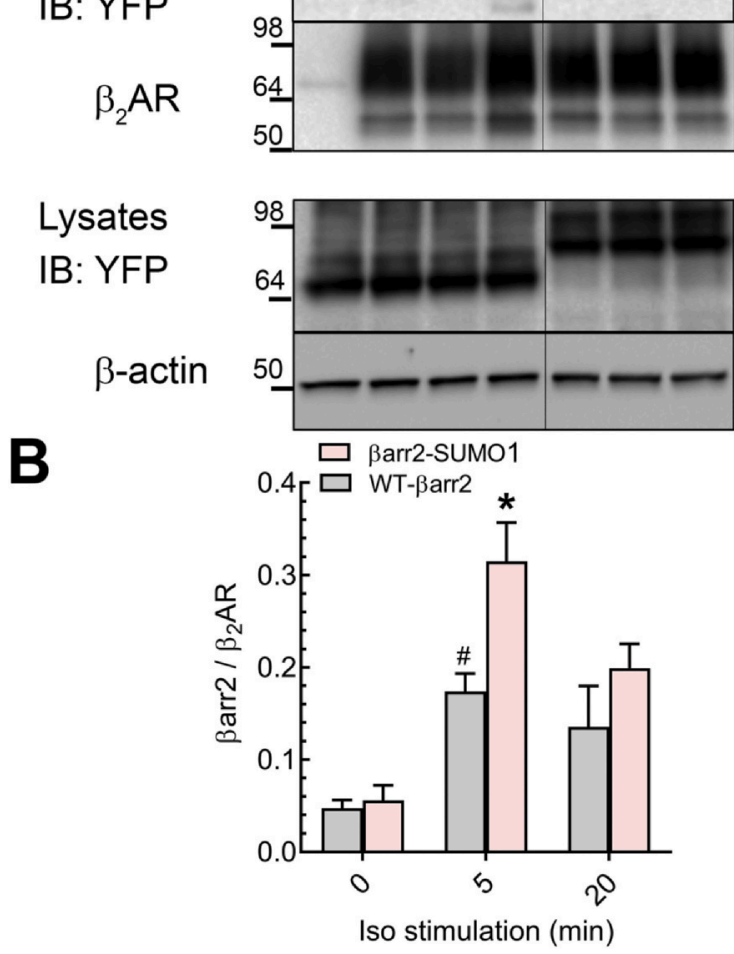

Fig. 4. $\beta$ arrestin2-SUMO1 fusion protein displays stronger association with agonist-activated $\beta_{2} \mathrm{AR}$ than $\beta$ arrestin2.

(A) HEK-293 cells stably expressing the FLAG- $\beta_{2}$ AR were transiently transfected with either vector, YFP- $\beta$ arr2-WT or YFP- $\beta$ arr2-SUMO1 and were exposed or not to Isoproterenol (Iso, $1 \mu \mathrm{M}$ ) for the indicated times. FLAG-tagged receptors were immunoprecipitated after chemical cross-linking and the IP was probed with an anti-GFP antibody that recognizes YFP (MBL International Corporation) and subsequently blots were stripped and reprobed with a $\beta_{2} \mathrm{AR}$ specific antibody, H-20. (B) Immunoreactivities of the different ßarr2 fusion proteins recovered were normalized to the cognate amount of receptors and are expressed as ratio of relative intensities of the labeled bands. Statistical comparison was done using two-way ANOVA and shown as means \pm SEM of 4 independent experiments. $\# p<0.05$ versus respective unstimulated condition; $* \mathrm{p}<0.05$ versus all other conditions, two-way ANOVA, Holm-Sidak's comparison.

293 cells. In addition, fusion of the cytoplasmic protein pyruvate kinase with SUMO1, did not localize pyruvate kinase to the nuclear membrane [34]. While YFP-SUMO1 was concentrated in the nucleus, and nucleoli, we detected very little Barrestin2-SUMO1 in the nucleus or nucleolus. Thus the subcellular distribution of $\beta$-arrestin-SUMO1 is different compared with YFP-SUMO1, and is not due to trafficking properties of SUMO1 itself, but rather represents the properties of ßarrestin2-SUMO1 chimera and might mimic the localization of persistently SUMOylated ßarrestin2. Furthermore, although ubiquitin and SUMO1 have high structural homology, $\beta$-arrestin-ubiquitin chimera was undetectable at the nuclear membrane (Fig. 2D).

\section{3. $\beta$ arrestin2-SUMO1 chimera associates with agonist-activated $\beta_{2} A R$ with higher affinity than Barrestin2}

We next compared the trafficking of $\beta$ arrestin2-SUMO1, and ßarrestin2, in HEK-293 cells with stable expression of the $\beta_{2} A R$. In quiescent cells we observed minimal colocalization of ßarrestin2 with the $\beta_{2} \mathrm{AR}$; upon agonist activation, we detected translocation of Barrestin2 (Fig. 3A, green) to the $\beta_{2} \mathrm{AR}$ (shown in red, Fig. 3A) at the plasma membrane after $5 \mathrm{~min}$ of agonist stimulation. However, after 20 min of agonist activation, ßarrestin2 and $\beta_{2} \mathrm{AR}$ dissociate from each other and no colocalization is detected. For Barrestin2-SUMO1 we detected plasma membrane translocation upon $\beta_{2} \mathrm{AR}$ agonist activation, and intriguingly we detected $\beta$ arrestin2-SUMO1 in endocytic vesicles. These $\beta_{2}$ AR- $\beta$ arrestin2-SUMO1 complexes persisted with longer agonist activation (Fig. 3B). Fig. 3C shows confocal images of cells stably expressing the $\beta_{2} \mathrm{AR}$ and transiently expressing YFP-SUMO1. In both quiescent and agonist-treated cells, the SUMO1 protein remained in the nucleus. SUMO1 and Ub share the same structural properties, and previously ßarrestin2-Ub chimera demonstrated a robust binding and endosomal colocalization with the $\beta_{2} \mathrm{AR}[9,14,35]$. Therefore, we next compared the endosomal trafficking of $\beta$ arrestin2-ubiquitin ( $\beta$ arrestin2-Ub) chimera with internalized $\beta_{2} \mathrm{ARs}$ (Fig. 3D). The magnitude of colocalization of internalized $\beta_{2}$ ARs and $\beta$ arrestin2-Ub was much greater than colocalization of $\beta$ arrestin2-SUMO1 and $\beta_{2}$ AR. Nonetheless, we observed an accelerated mobilization of $\beta_{2} \mathrm{AR}$ and $\beta$ arrestin2-SUMO1 in endosomal vesicles than with ßarrestin2-Ub (compare $5 \mathrm{~min}$, Iso images, Fig. 3B and D).

We also evaluated the association of $\beta$ arrestin2-SUMO1 with $\beta_{2} \mathrm{AR}$ complexes, using chemical crosslinking (see methods) [9] and co-immunoprecipitation (Fig. 4). We used HEK-293 cells stably expressing FLAG- $\beta_{2}$ AR and transiently expressed $\beta$ arrestin2, or $\beta$ arrestin2-SUMO1. We immunoprecipitated the receptors under nonstimulated or stimulated conditions (5 and $20 \mathrm{~min}, 1 \mu \mathrm{M}$ isoproterenol), and detected ßarrestin2 or ßarrestin2-SUMO1 by Western blotting (Fig. 4A). ßarrestin2-SUMO1 binds to activated receptors $\sim 2-3$ fold more than the WT Barrestin2 at $5 \mathrm{~min}$ of isoproterenol stimulation (Fig. 4B). Accordingly, ßarrestin2-SUMO1, has an increased affinity for agonist-activated $\beta_{2}$ ARs.

We next assessed whether the recruitment of ßarrestin2 fusion proteins to the $\beta_{2} \mathrm{AR}$ can be measured in living cells using the BRETbased proximity assay. In this approach, we used titrations curves in which HEK-293 T cells were transiently transfected with a fixed amount of donor-tagged receptor subunits genetically fused to Renilla Luciferase ( $\beta_{2}$ AR-Rluc) and increasing amounts of YFP $\beta$ arrestin2 acceptor constructs (YFP- $\beta$ arrestin2, YFP- $\beta$ arrestin2-SUMO1 or YFPßarrestin2-Ub) (Fig. 5, A-C). Cells were then treated for $5 \mathrm{~min}$ with isoproterenol $(1 \mu \mathrm{M})$ and BRET measurements followed immediately afterward. Minimal BRET signal was detected in cells that were not exposed to the agonist, which could be caused by random collisions between energy donor and acceptors or from negligible constitutive ßarrestin2 recruitment [36]. However, when exposed to the agonist, increasing concentrations of the acceptor construct induced a progressive increase in BRET signal until increments became minimal $[28,36]$. This saturable increase in energy transfer at $\beta$ arrestin $2 / \beta_{2} A R$ interfaces, indicates that all fusion versions of the regulatory protein were specifically recruited to the receptor.

The specific ligand-induced ßarrestin2 recruitment effects were calculated by subtracting the BRET signal observed in control cells from the total signal obtained when exposed to the agonist (Fig. 5D). For the different pairs tested, YFP-ßarrestin2-SUMO1 showed the highest change in the net BRET value for the protein interaction with $\beta_{2} \mathrm{AR}$ (bar graph inset of Fig. 5D) among ßarrestin2 constructs. Taken together with the confocal and immunoprecipitation analyses, we infer that YFPßarrestin2-SUMO1 adopts a conformation that is more suitable to interact with the C-terminus of the $\beta_{2} \mathrm{AR}$ than YFP-ßarrestin2. On the other hand, although YFP-ßarrestin2-Ub shows robust recruitment to 

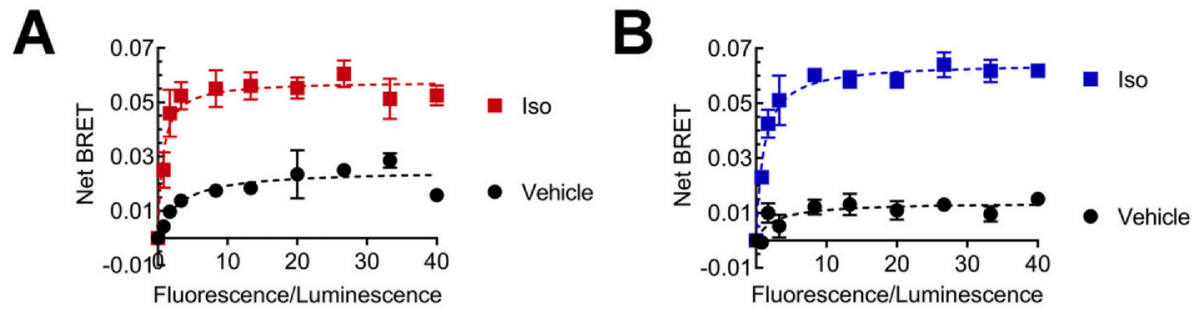
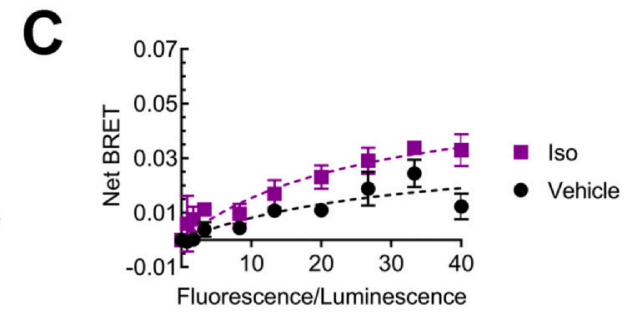
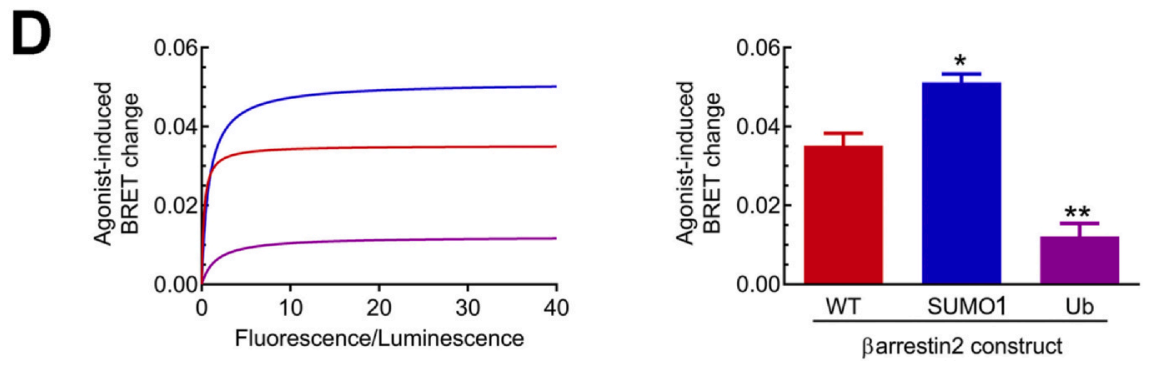

Fig. 5. BRET titration curves of ßarrestin2, ßarrestin2-SUMO1, ßarrestin2-Ub defining recruitment to the $\beta_{2} \mathrm{AR}$.

BRET signals were measured in HEK-293 T cells transiently transfected with a fixed amount of $\beta_{2}$ AR-Rluc and increasing amount of either YFP- $\beta$ arr2-WT (A), YFPßarr2-SUMO1 (B) or YFP-ßarr2-Ub (C). Cells were stimulated (squares) or not (circles) with Iso $(1 \mu \mathrm{M})$ for 5 min. (D) Agonist-induced BRET changes were obtained by subtracting the vehicle curve from the Iso-stimulated curve and correspond to the agonist effect. Histogram represent Bmax values generated from agonist-induced BRET changes curves. Significance of agonist-induced changes was established by one-way ANOVA comparing signals generated by YFP- $\beta$ arr2-WT to those generated by YFP-ßarr2-SUMO1 or YFP-ßarr2-Ub cells ${ }^{*} p<0.05 ;{ }^{* *} p<0.01$. Results correspond to mean \pm SEM of 3 independent experiments performed in duplicates.

the membrane and colocalization with the receptor after 5 min agoniststimulation in confocal experiments (Fig. 3D), and in co-immunoprecipitation analyses $[9,35]$, it showed the lowest ligand-induced BRET signal. Therefore, although YFP- $\beta$ arrestin2-Ub fusion protein associates tightly with the $\beta 2 \mathrm{AR}[9,14,35,37]$, it is likely that the orientation of YFP-ßarrestin2-Ub poises it in a conformation sub-optimal for BRET [32]. Alternatively, the reciprocal patterns observed for BRET for the ßarrestin2-SUMO1 (increase in BRET) and ßarrestin2-Ub (decrease in BRET) compared with ßarrestin2 also suggests the existence of a specific but different ligand-induced conformation for each of the ßarrestin2 fusion proteins.

\subsection{Barrestin2-SUMO1 shows enhanced affinity with the D2R but not with the V2R}

We next established the specificity of our observations with the $\beta_{2} \mathrm{AR}$, by assessing whether $\beta$ arrestin2-SUMO1 could interact with other GPCRs in an enhanced capacity when compared with ßarrestin2. We chose the $\mathrm{D}_{2} \mathrm{R}$, which possesses a similar trafficking 'Class A' plasma membrane recruitment of $\beta$ arrestin2 like the $\beta_{2} A R$, and the $V_{2} R$, which has a very high affinity for ßarrestin2 association. The $D_{2} R$ leads to activation of the inhibitory G protein (Gi) $[38,39]$, recruits ßarrestin2 transiently at the plasma membrane and internalizes without bound Barrestin upon activation [40]. The $\mathrm{V}_{2} \mathrm{R}$ couples to the stimulatory $\mathrm{G}$ protein (Gs) [41] but co-traffics with bound ßarrestin2, and forms ßarrestin2-ERK signaling complexes at endosomes [42,43]. Notably, because of its high affinity to ßarrestins, $\mathrm{V}_{2} \mathrm{R}$ C-tail residues are often appended to other GPCRs to stabilize ßarrestin2-receptor complex $[43,44]$.

We evaluated agonist-induced ßarrestin 2 recruitment to the $D_{2} R$ by confocal microscopy (Fig. 6), coimmunoprecipitation (Fig. 7) and by BRET (Fig. 8) in the same manner as described for the $\beta_{2}$ AR (Figs. 3, 4, and 5). In quiescent cells, the overall patterns of $\beta$ arrestin2, $\beta$-arrestin2SUMO1, SUMO1, and ßarrestin2-Ub sub-cellular distributions in HEK293 cells stably expressing the $D_{2} R$, were identical to the patterns observed with the $\beta_{2} \mathrm{AR}$ expressing cells (Figs. 3 and 6). Although $\beta$ arrestin2 translocates to the plasma membrane upon $D_{2} R$ activation, its interaction with the $D_{2} R$ is not stable (Fig. 6A). In contrast, both $\beta$ arrestin2-SUMO1 (Fig. 6B) and ßarrestin2-Ub (Fig. 6D), associate stably with the $D_{2} R$ s localized on endocytic vesicles along with internalized $\mathrm{D}_{2}$ Rs. We also observed substantial $\mathrm{D}_{2} \mathrm{R}$ internalization in endocytic vesicles in cells expressing ßarrestin2-SUMO1 compared to cells expressing ßarrestin2 (Fig. 6A \& 6B). On the other hand, there was no change in YFP-SUMO1 localization after $\mathrm{D}_{2} \mathrm{R}$ agonist-activation (Fig. 6C).

We determined the association of ßarrestin2-SUMO1 with $\mathrm{D}_{2} \mathrm{R}$ complexes, using co-immunoprecipitation assay (Fig. 7). We used HEK293 cells stably expressing $\mathrm{HA}-\mathrm{D}_{2} \mathrm{R}$ and transiently expressed $\beta$ arrestin2, or Barrestin2-SUMO1. We immunoprecipitated the receptors under nonstimulated or stimulated conditions ( 5 and $20 \mathrm{~min}, 10 \mu \mathrm{M}$ dopamine), and detected $\beta$ arrestin2 or $\beta$ arrestin2-SUMO1 by Western blotting (Fig. 7A). ßarrestin2-SUMO1 binds to activated receptors $\sim 3-4$ fold more than the WT $\beta$ arrestin2 at $20 \mathrm{~min}$ of stimulation (Fig. 7B), although no significant difference in $\mathrm{D}_{2} \mathrm{R}$-binding affinity was observed between $\beta$ arrestin2 and $\beta$ arrestin2-SUMO1 at five minutes of agoniststimulation. Thus, SUMOylation status of ßarrestin2 can enable its persistent association with internalized $\mathrm{D}_{2}$ Rs.

Concentration-dependent increase in BRET signals between Rluctagged $\mathrm{D}_{2} \mathrm{R}$ and YFP-tagged ßarrestin2 constructs corresponding to ßarrestin2 recruitment to the receptor was observed (Fig. 8). As detected for the $\beta_{2} \mathrm{AR}$ system, the agonist-mediated increase in energy transfer was greater with YFP-ßarrestin2-SUMO1 than with YFP-ßarrestin2 for the $D_{2} R$; additionally, the net-BRET signal was only minimal for YFP-Barrestin2-Ub upon receptor stimulation (Fig. 8). We attribute the weak signals for observed $\mathrm{D}_{2} \mathrm{R}$ - $\beta$ arrestin2-Ub association by BRET to its conformation being unfavorable for BRET.

We did not find any significant differences between ßarrestin2 and ßarrestin2-SUMO1 in the pattern of sub-cellular colocalization with activated $\mathrm{V}_{2}$ Rs (Fig. 9A) and in the magnitude of interaction defined by BRET (Fig. 9B). Concordantly, both ßarrestin2 and ßarrestin2-SUMO1 showed equivalent binding with agonist activated $\mathrm{V}_{2}$ Rs as determined by co-immunoprecipitation assays (Fig. 9C). We also found constitutive interaction of YFP-ßarrestin2-SUMO1 and HA- $\mathrm{V}_{2}$ Rs which could be due to an increased binding affinity due to exposure of hydrophobic regions 
A
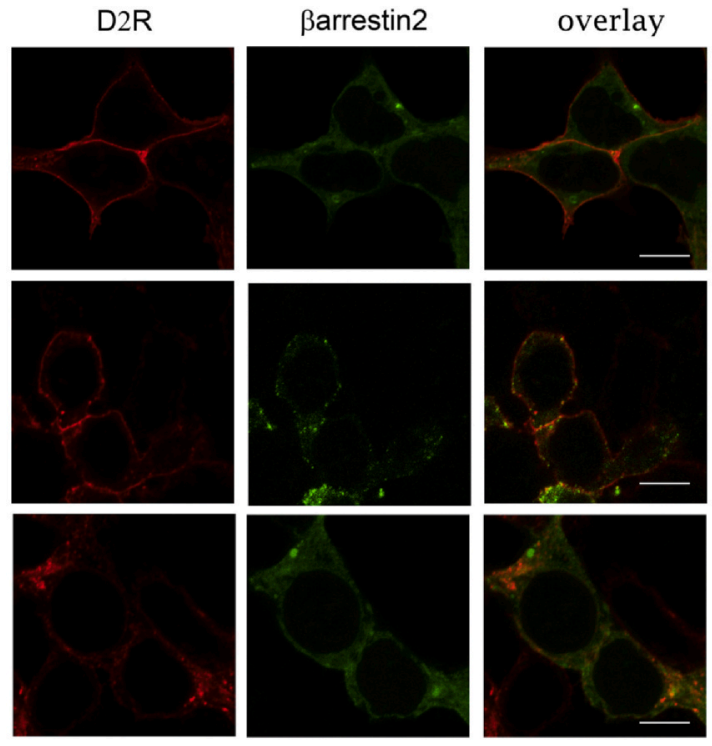

B
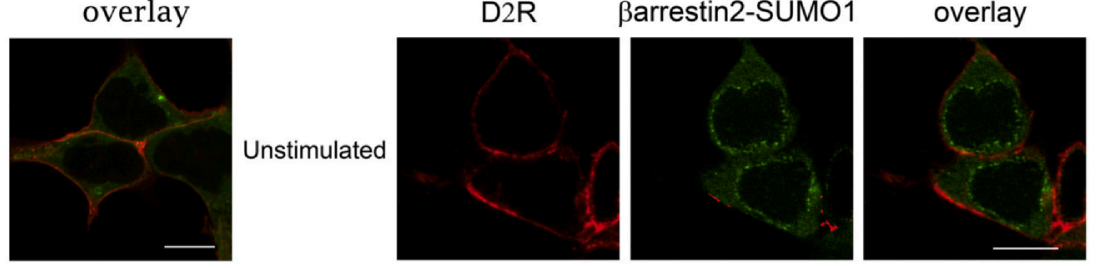

5 min Dop
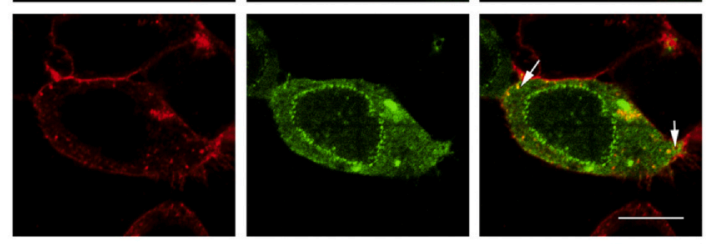

20min Dop
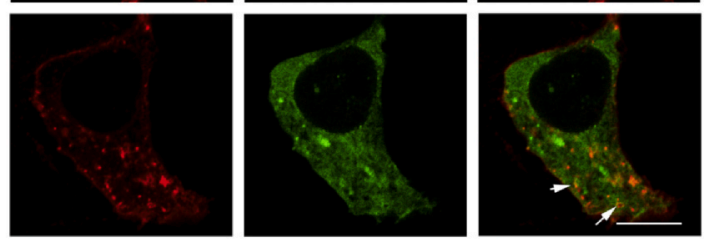

C

D2R
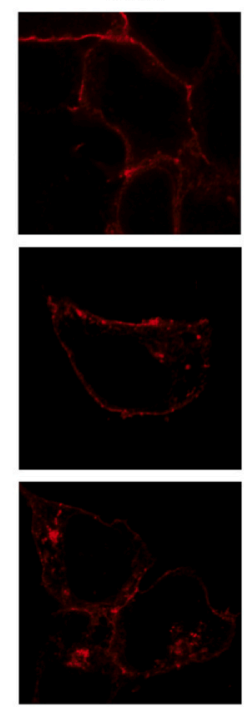

SUMO1
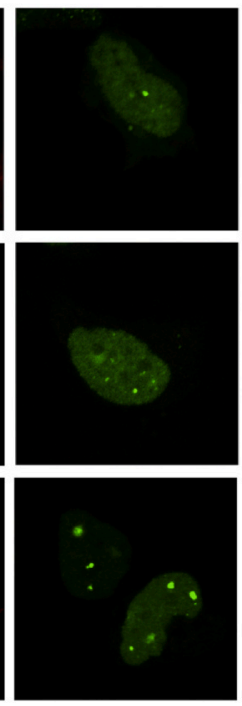

overlay
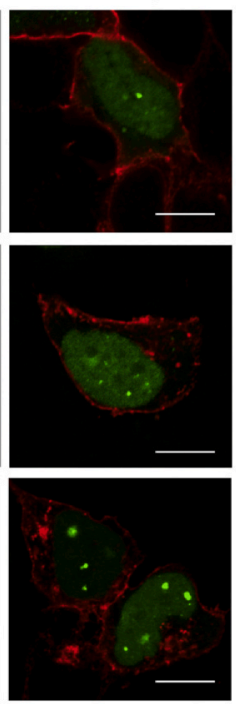

D

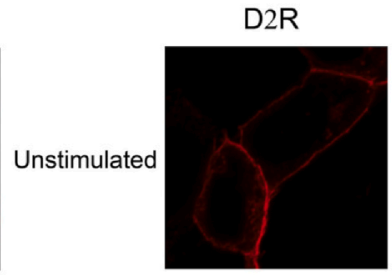

ßarrestin2-Ub
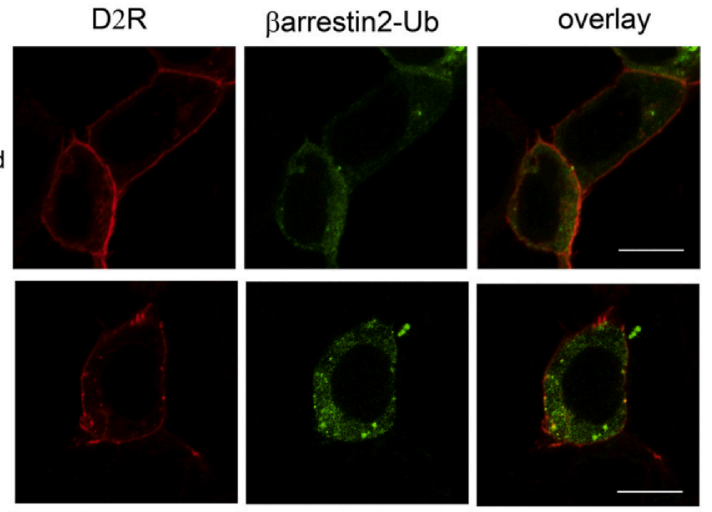

20min Dop
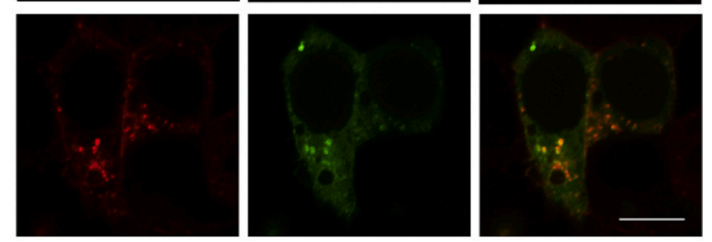

Fig. 6. Trafficking of $\beta$ arrestin2, $\beta$ arrestin2-SUMO1, ßarrestin-Ub in response to dopamine $\mathrm{D} 2$ receptor $\left(\mathrm{D}_{2} \mathrm{R}\right)$ stimulation.

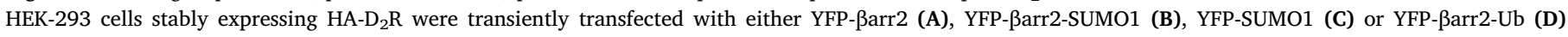
constructs. Cells were serum-starved for $4 \mathrm{~h}$ then stimulated or not with dopamine (Dop; $10 \mu \mathrm{M}$ ) for the indicated times. Cells were fixed, permeabilized and immunostained for the $\mathrm{D}_{2} \mathrm{R}$ using anti-HA antibody. $\mathrm{D}_{2} \mathrm{R}$ detection is shown in red, YFP fluorescence in green and the overlay panels in yellow which represent colocalization. Images shown are from one of two identical experiments. White arrows in panel B overlay images indicate colocalization of ßarrestin2-SUMO1 and $\mathrm{D}_{2} \mathrm{R}$ in endosomes. Scale bars $=10 \mu \mathrm{m}$. (For interpretation of the references to colour in this figure legend, the reader is referred to the web version of this article.)

with detergent solubilization. Nonetheless, we could not detect a difference in binding affinity of ßarrestin2 versus ßarrestin2-SUMO1 with agonist activated $\mathrm{V}_{2} \mathrm{Rs}$ by any of the approaches, namely sub-cellular distribution by confocal analyses, BRET, and coimmunoprecipitation. Because activated and phosphorylated $\mathrm{V}_{2} \mathrm{R}$ has a high affinity for $\beta$ arrestins as evidenced by the utilization of $V_{2} R$ carboxyl tail residues to enhance $\beta$ arrestin binding to GPCRs that have low affinity for ßarrestins $[43,45]$, we believe that appending SUMO1 did not result in a further increase in $\mathrm{V}_{2} \mathrm{R}$-ßarrestin2 association.

\subsection{SUMOylation of Barrestin2 facilitates its protein interactions at the nuclear membrane}

Although $\beta$ arrestins were discovered in the context of GPCR regulation, it is evident that they play a much broader role and regulate many types of receptors, and scaffold enzymes of the ubiquitination pathway and kinase phosphorylation cascades $[2,13,46]$. In HeLa cells subjected to mitotic synchronization, SUMO1was localized at the nuclear membrane during interphase and at mitotic spindles during cell division, but the paralogs, SUMO2 and SUMO3 did not show these patterns of localization [24]. This was attributed to the changes in RanGAP1 sub-cellular localization and the paralog-specific conjugation of RanGAP1 with SUMO1 [24]. Interestingly, RanGAP1 is one of the 
A

\begin{tabular}{|c|c|c|}
\hline $\begin{array}{l}\text { YFP-Barr2 } \\
\end{array}$ & WT & SUMO1 \\
\hline $\mathrm{HA}-\mathrm{D}_{2} \mathrm{R}$ & & \\
\hline $\mathrm{DA}(\min )$ & \begin{tabular}{l|l|l|}
0 & 5 & 20 \\
\end{tabular} & \begin{tabular}{l|l|l|}
0 & 5 & 20 \\
\end{tabular} \\
\hline IP: HA & $4 \ldots$ & - \\
\hline$D_{B}$ & 64 & $m$ \\
\hline $\begin{array}{l}\text { Lysates } \\
\text { I. YFFP }\end{array}$ & 64- - & - \\
\hline GAPDI & & - \\
\hline
\end{tabular}

B

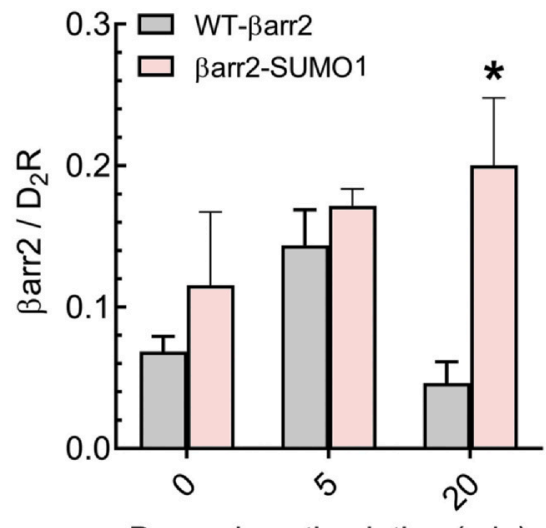

Dopamine stimulation ( $\mathrm{min})$

Fig. 7. ßarrestin2-SUMO1 fusion protein displays stronger association with agonist-activated $\mathrm{D}_{2} \mathrm{R}$ than $\beta$ arrestin2.

(A) HEK-293 cells stably expressing the HA- $\mathrm{D}_{2} \mathrm{R}$ were transiently transfected

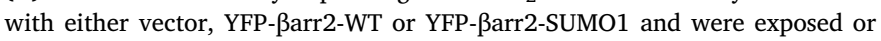
not to dopamine (DA, $10 \mu \mathrm{M}$ ) for the indicated times. HA-tagged receptors were immunoprecipitated with anti-HA magnetic beads and the IP was probed with an anti-GFP antibody that recognizes YFP (MBL, International) and subsequently blots were stripped and reprobed with an antibody that detects HA. (B) ßarrestin2 and ßarrestin2-SUMO1 bands were divided by respective $H A-D_{2} R$ band and the ratios are plotted for each sample from three independent experiments. Statistical comparison was done using two-way ANOVA and shown as means \pm SEM of 3 independent experiments. * $\mathrm{p}<0.05$ versus all other conditions, two-way ANOVA, Holm-Sidak's comparison.

few SUMOylated proteins that does not localize in the nucleus, and SUMOylation of RanGAP1 is required, but not sufficient for its localization at the nuclear envelope [34]. Studies have also indicated that mere SUMO1 fusion to cytosolic proteins does not target them to locate to nuclear membranes, because fusion of SUMO1 to pyruvate kinase does not instigate its localization at the nuclear envelope [34].

In HEK-293 cells used in our studies, SUMO1 by itself is not localized at the nuclear membrane (Figs. 2, 4C, and 6C), and only ßarrestin2-SUMO1 is localized at the nuclear membrane (Figs. 2, 4B and $6 \mathrm{~B})$. Interactome studies have revealed that $\beta$ arrestin2 but not $\beta$ arrestin1 can bind RanGAP1 [47]; moreover, the localization of RanGAP1 at the nuclear rim [34] overlaps that of the Barrestin2-SUMO1 construct (Fig. 2). We hypothesized that ßarrestin2 and its SUMOylation status can regulate RanGAP1 protein association. It is well established that RanGAP1 expressed in cells predominantly in the SUMOylated state. This is illustrated in our immunoblots (Fig. 10), in which the RanGAP1 antibody detects two bands, SUMO-RanGAP1 ( $~ 90 \mathrm{kDa})$ and RanGAP1 $(\sim 70 \mathrm{kDa})$. When we overexpressed ßarrestin2 in HEK-293 cells, we did not detect a dramatic change in the levels of SUMO1-RanGAP1 $(90 \mathrm{kDa}$ band, Fig. $10 \mathrm{~A}$ ). On the other hand, in cells with ßarrestin2 overexpression, the unmodified RanGAP1 band $(\sim 70 \mathrm{kDa})$ was increased by $50 \%$ of the levels in vector transfected cells (Fig. 10B).

In HEK-293 and HEK-293 T cells, which have different levels of endogenous ßarrestin2 expression levels, ßarrestin2 knockdown by siRNA had no effect on steady-state levels of SUMO-RanGAP1 (Fig. 10C, Fig. S2). Nonetheless, we observed a significant decrease in the unmodified RanGAP1 band (Fig. 10 C-D, Fig. S2). One possibility for the apparent decrease in RanGAP1 in ßarrestin2 depleted cells could be an increase in RanGAP1 SUMOylation by Ran binding protein 2 (RanBP2) SUMO E3 ligase [48], or a decrease in RanGAP1 deSUMOylation by SENP1 that binds ßarrestin2 [16]. Since most of the RanGAP1 in cells exists as the SUMOylated $90 \mathrm{kDa}$ species, and since the RanGAP1-specific antibody detects the $90 \mathrm{kDa}$ band with high avidity, we were unable to discern corresponding changes in the SUMOylated RanGAP1 levels. On the other hand, these effects of Barrestin2 expression on the expression level of unmodified RanGAP1 could be SUMO1-independent.

To further address the role of ßarrestin2-SUMOylation on the subcellular localization of RanGAP1, we evaluated the colocalization of endogenously expressed RanGAP1 and overexpressed ßarrestin2, or $\beta$ arrestin2-SUMO1 in HEK-293 cells $\pm \beta_{2} \mathrm{AR}$ agonist stimulation (Fig. 10E). We detected minimal colocalization of $\beta$ arrestin2 and RanGAP1 at the nuclear envelope (one or two punctate structures per cell colocalizing both proteins). However, we detected a dramatic increase in colocalization between ßarrestin2-SUMO1 and RanGAP1, in quiescent cells as well as in cells stimulated with $\beta_{2} \mathrm{AR}$ agonist (Fig. 10E, middle row). We also tested if ßarrestin2-Ub changes the localization of RanGAP1 (Fig. 10E). We failed to detect any significant changes in RanGAP1 localization as well as any colocalization of ßarrestin2-Ub with RanGAP1, suggesting that ubiquitination of ßarrestin2 may negatively regulate its interaction with RanGAP1.

To complement our confocal assessment, we performed co-immunoprecipitation of overexpressed YFP-ßarrestin2, or YFP-ßarrestin2SUMO1 and probed for endogenous RanGAP1 in the pull-downs of YFP proteins (Fig. 10F). As a negative control, we used ßarrestin2 that has non-YFP tag to ascertain non-specific binding. In these assays, only the SUMOylated form of Ran-GAP1 associated with ßarrestin2 and the unmodified RanGAP1 showed weak or no interaction (Fig. 10F). We detected ßarrestin2-SUMO-RanGAP1 binding in the absence of agonist, which was slightly enhanced by a five-minute agonist-stimulation (1.3 \pm 0.4 fold, $n=3$ ). Barrestin2-SUMO1 also associated only with SUMO-RanGAP1, but quite strikingly, we detected a macromolecular complex of ßarrestin2 and RanGAP1, detectable by immunoblotting with either ßarrestin IgG or RanGAP1 IgG (Fig. 10F). We further tested the interactions between $\beta$ arrestin2 and endogenous RanGAP1 (Fig. S2) by overexpressing FLAG-tagged constructs: ßarrestin2, ßarrestin2SUMO1. Here again, we detected ßarrestin2 association with SUMORanGAP1 and a macromolecular complex of ßarrestin2-SUMO1 and RanGAP1 (Fig. S2). These data suggest that ßarrestin2-SUMOylation increases its binding affinity with RanGAP1, and perhaps, SUMOylation of ßarrestin2 may be required for its localization at the nuclear membrane and interaction with RanGAP1. Additionally, ßarrestin2 might regulate steady state levels of de-SUMOylated RanGAP1, which could proceed concurrently or independently of SUMO1 conjugation of RanGAP1. Taken together, these results suggest a novel role for ßarrestin2 in harmonizing conjugation/deconjugation of SUMO1 at the nuclear membrane.

\section{Discussion}

By analyzing a ßarrestin2-SUMO1 fusion protein that remains persistently SUMOylated we demonstrate that the intracellular trafficking 

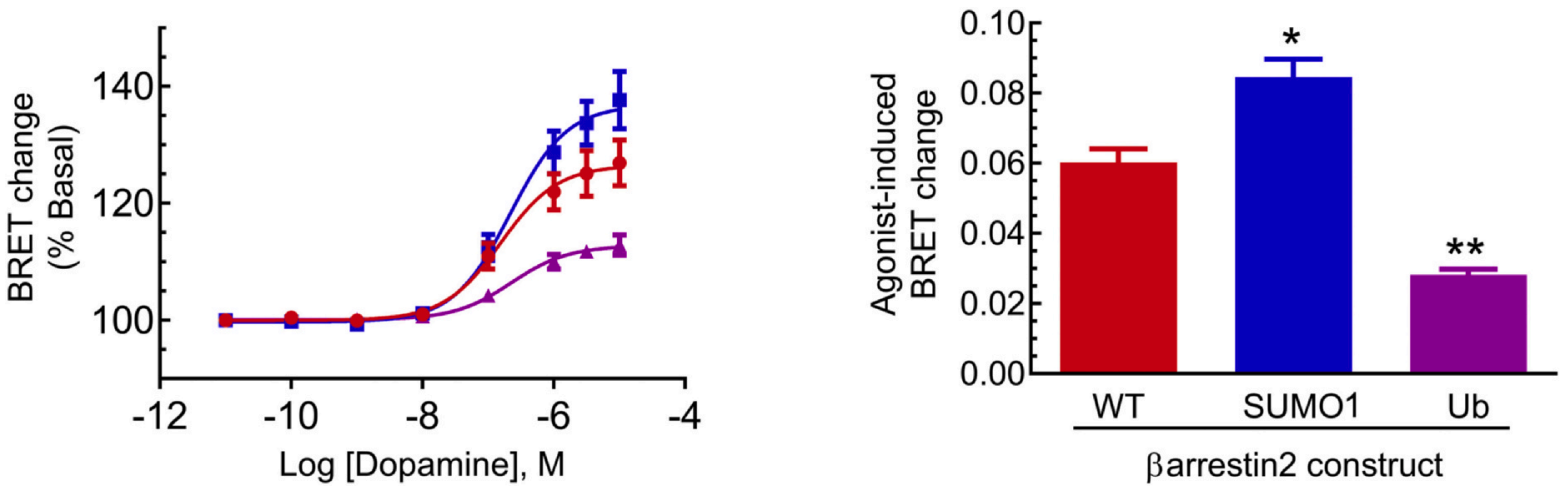

Fig. 8. Determination of BRET between $\beta$-arrestin2 fusion proteins and agonist-activated $D_{2} R$.

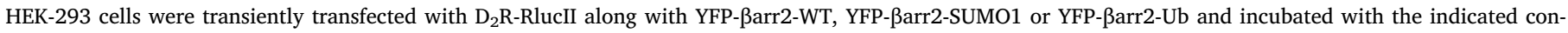

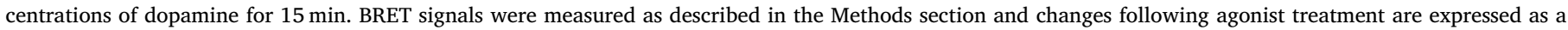

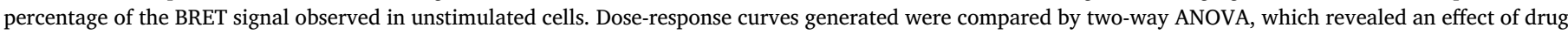

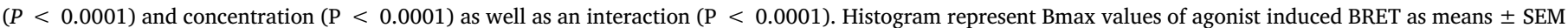

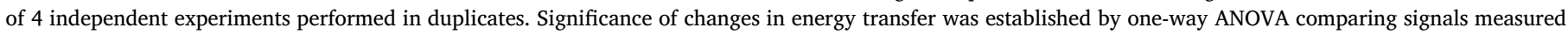
for the recruitment of $\beta$ arr2 fusion proteins to $\mathrm{D}_{2} \mathrm{R}$-RlucII ${ }^{*} \mathrm{p}<0.01 ;{ }^{* *} p<0.001$.

A
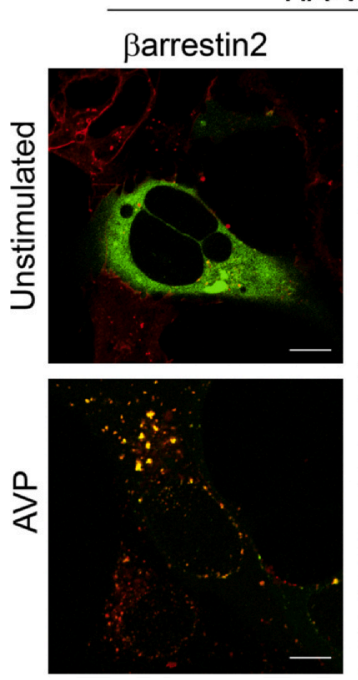

HA-V2R
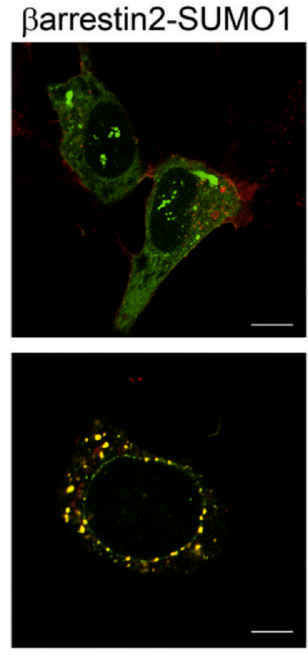

B

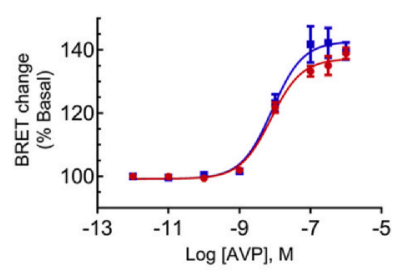

C

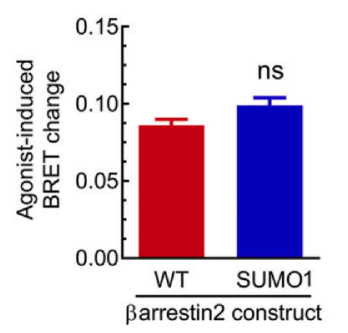

D

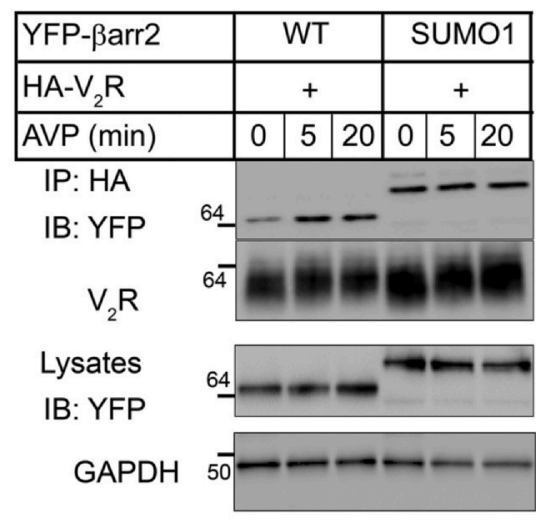

Fig. 9. ßarrestin2 and ßarrestin2-SUMO1 bind to the activated $V_{2} R$ with similar affinities.

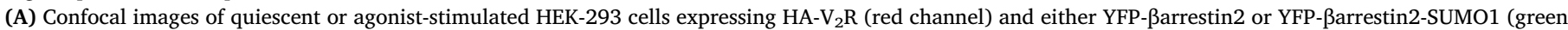

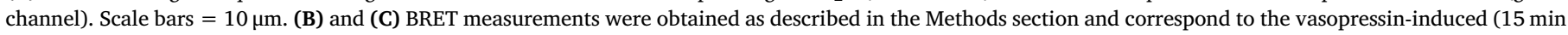

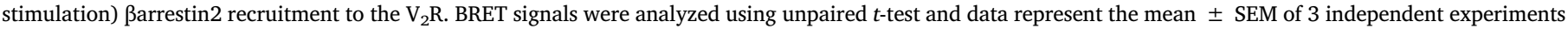

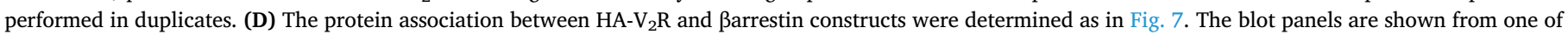
two independent experiments. (For interpretation of the references to colour in this figure legend, the reader is referred to the web version of this article.)

of ßarrestin2 is influenced by covalent modification by SUMO1. Although domain-specific conformational changes in Barrestins [49-51] have been linked with their binding to representative GPCRs and some protein partners, it is likely that additional molecular changes in ßarrestin would be required for its interaction with the broader repertoire of cell-surface receptors, cytosolic and nuclear proteins that can potentially associate with ßarrestins and affect signal transduction. In this context, dynamic SUMOylation provides a new molecular mechanism to direct ßarrestin to specific sub-cellular compartments and interact with cellular proteins. Moreover, although Ub and Ubls such as SUMO share marked structural similarity, the biological consequences of SUMOylation are distinct from that of ubiquitination [52-56]. It is highly likely that many of ßarrestin's functional roles in GPCR-induced signaling pathways leading to diverse cellular activities, such as mitogenesis, apoptosis, differentiation and cell migration can be regulated by either ubiquitination or SUMOylation or perhaps by both modifications.
We also present a novel role of ßarrestin2 SUMOylation: binding and potential regulation of RanGAP1, which is a GTPase-activating protein for the small G protein, Ran [57]. RanGAP1 is localized in the cytoplasm and at the nuclear envelope; incidentally, SUMOylated RanGAP1 localizes at the nuclear membrane and the un-SUMOylated RanGAP1 is mostly cytoplasmic [34]. RanGAP1 forms a functional complex with RanBP2, ubiquitin carrier protein 9 (Ubc9, which is the unique E2 enzyme for SUMO conjugation), and SUMO1 at the nuclear pore complex [58]. Nonetheless, whether SUMOylation of RanGAP1 is a cause or consequence of its localization at the nuclear membrane is unknown. Prior studies have linked SUMOylation with localization of RanGAP1 and not with its GAP activity [34]. RanGAP1 was identified as a potential ßarrestin2 binding protein in interactome studies [47], and our co-immunoprecipitation assays reveal that ßarrestin2 mostly binds the SUMOylated RanGAP1. Additionally, the localization of ßarrestin2-SUMO1 at the nuclear membrane suggests that RanBP2 complex, which acts as a composite SUMO E3 ligase can SUMOylate 
A

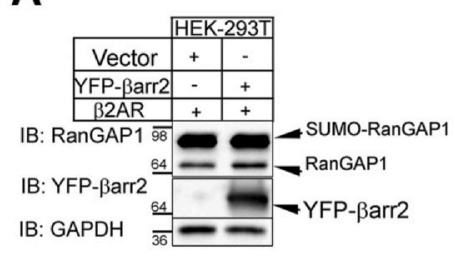

B

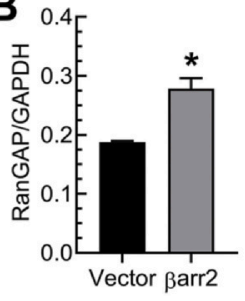

C

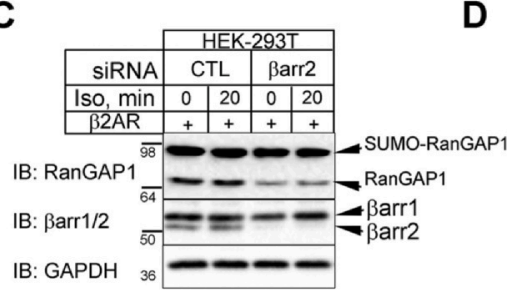

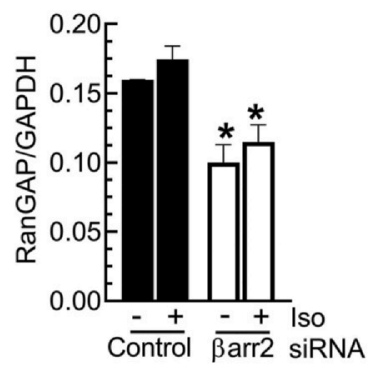

E
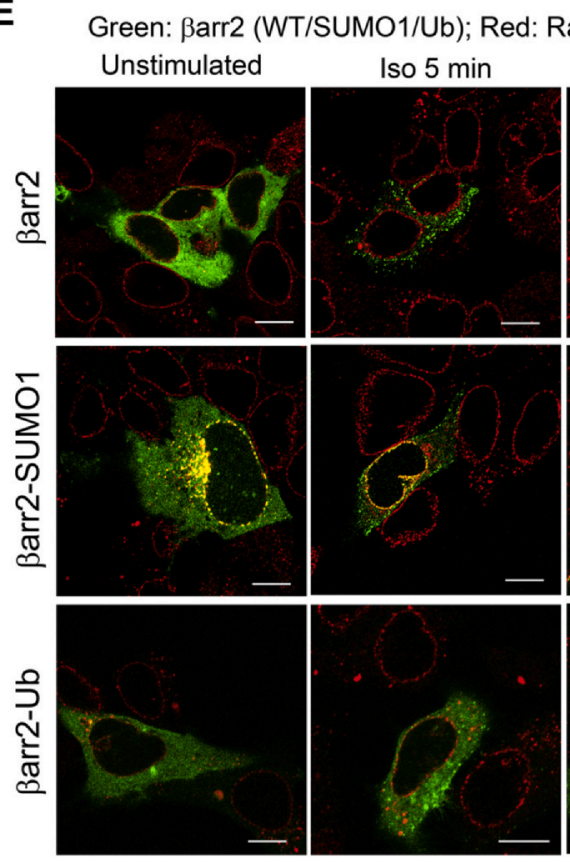

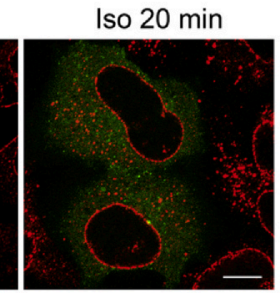

$\mathbf{F}$
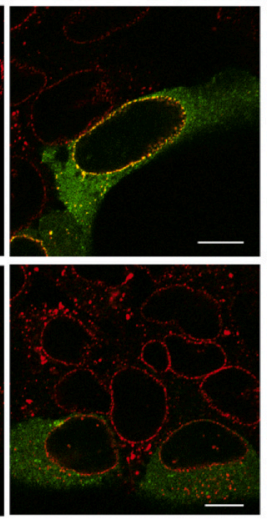

Fig. 10. Effect of ßarrestin2 expression and ßarrestin2 SUMOylation on RanGAP1.

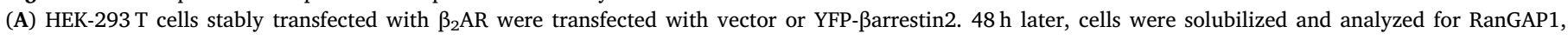

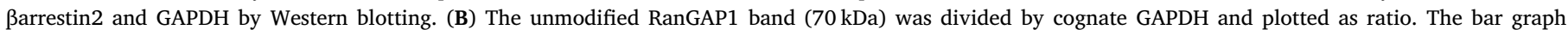

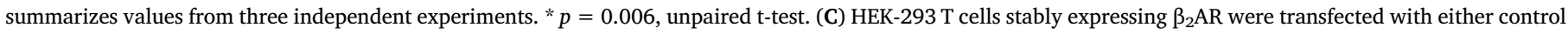

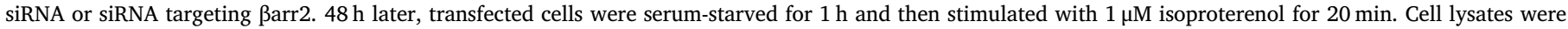

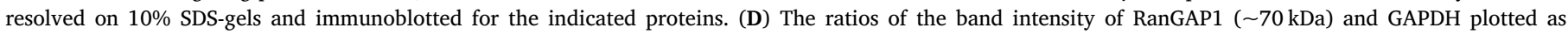

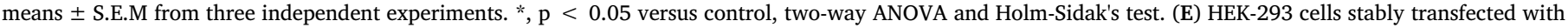

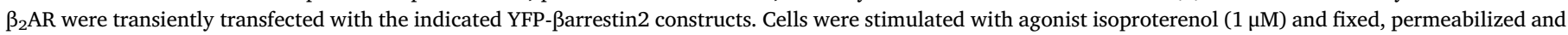

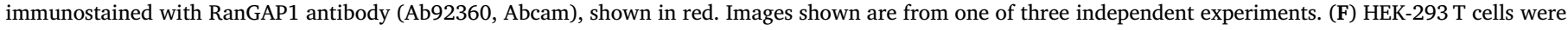

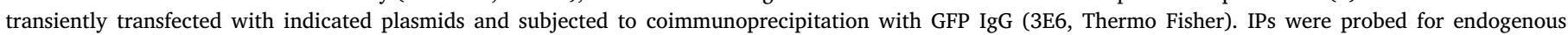

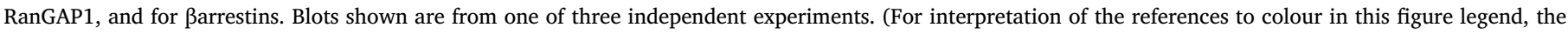
reader is referred to the web version of this article.)

ßarrestin2 [59]. Furthermore, studies have shown that $\beta$ arrestin2, but not ßarrestin1 scaffolds Ubc9 [60,61], that can lead to SUMOylation of RanGAP1 among other protein substrates. On the other hand, the decrease in just the unmodified RanGAP1 after ßarrestin2 knockdown suggests a role for $\beta$ arrestin2 in scaffolding deSUMOylase activity to tightly regulate SUMO-RanGAP1 at the nuclear membrane. Further in depth studies are needed to establish the exact role of ßarrestin2 and RanGAP1 interaction and to discern whether this impacts Ran GTP loading, or Ran nucleocytoplasmic shuttling.

Our characterization of $\beta$ arrestin2-Ub and $\beta$-arrestin2-SUMO1 chimeric proteins, show that these modifications improve the affinity of ßarrestin2 for activated GPCRs. However, we observed differences for ßarrestin2-Ub/GPCR interaction based on the assay methodology: while confocal imaging showed tight stable complexes of ßarrestin2$\mathrm{Ub} / \beta_{2} \mathrm{AR}$, as well as $\beta$ arrestin2-Ub/ $\mathrm{D}_{2} \mathrm{R}$, BRET assays showed weak signal for $\beta$ arrestin2-Ub's interaction with both these GPCRs. We attribute the low level in BRET signal detected to the conformation of YFP-ßarrestin2-Ub being unfavorable to receive energy from the donor
[32]. Additionally the reciprocal patterns for BRET observed for the two ßarrestin2 fusion proteins as compared with the wild type also suggests that these two chimeras have distinct conformations making them either conducive or not for energy transfer. On the other hand, the increase in BRET observed for ßarrestin2-SUMO1 with GPCRs that have weak affinity for unmodified ßarrestin2, suggest that ßarrestin2SUMO1 has a potential utility to screen for GPCR ligands that may induce only a transient or unstable recruitment of ßarrestin2. We also found that SUMO1-fusion did not further enhance binding of ßarrestin2 with the $V_{2} R$, which engages ßarrestin2 tightly based on the V2R's carboxyl tail phosphorylation motif [62]. We believe that for GPCRs that lack such a phosphorylation motif, ßarrestin2 binding can be boosted by appending additional interaction surfaces as accorded by ubiquitin or SUMO1.

Although Ub and SUMO are considered as 'protein cousins' and share structural homology, covalent ubiquitination and SUMOylation may poise ßarrestin2 in unique structural conformations, providing distinct protein association platforms for various ßarrestin-binding 
partners, which bear non-covalent ubiquitin and/or SUMO binding domains $[63,64]$. Future in-depth studies are needed to identify site(s) of persistent SUMOylation in ßarrestin2, and how the downstream outcomes of SUMOylation intersect with those generated by ubiquitination in ßarrestin-dependent signaling pathways.

\section{Acknowledgements}

We thank Pierre-Yves Jean-Charles for making the FLAG-ßarrestin2SUMO1 plasmid. We also thank Teague Cole for technical assistance at the early stages of this project. We are grateful to the funding support from the Edna and Fred L. Mandel Jr Foundation.

\section{References}

[1] S.M. DeWire, S. Ahn, R.J. Lefkowitz, S.K. Shenoy, Beta-arrestins and cell signaling, Annu. Rev. Physiol. 69 (2007) 483-510.

[2] Y.K. Peterson, L.M. Luttrell, The diverse roles of arrestin scaffolds in G proteincoupled receptor Signaling, Pharmacol. Rev. 69 (2017) 256-297.

[3] X. Tian, D.S. Kang, J.L. Benovic, Beta-arrestins and G protein-coupled receptor trafficking, Handb. Exp. Pharmacol. 219 (2014) 173-186.

[4] M.G. Caron, L.S. Barak, A brief history of the beta-arrestins, Methods Mol. Biol. 1957 (2019) 3-8.

[5] L.M. Luttrell, J. Wang, B. Plouffe, J.S. Smith, L. Yamani, S. Kaur, P.Y. Jean-Charles, C. Gauthier, M.H. Lee, B. Pani, J. Kim, S. Ahn, S. Rajagopal, E. Reiter, M. Bouvier, S.K. Shenoy, S.A. Laporte, H.A. Rockman, R.J. Lefkowitz, Manifold roles of betaarrestins in GPCR signaling elucidated with siRNA and CRISPR/Cas9, Sci. Signal. 11 (2018).

[6] S.K. Shenoy, R.J. Lefkowitz, Beta-arrestin-mediated receptor trafficking and signal transduction, Trends Pharmacol. Sci. 32 (2011) 521-533.

[7] F.T. Lin, W. Chen, S. Shenoy, M. Cong, S.T. Exum, R.J. Lefkowitz, Phosphorylation of beta-arrestin2 regulates its function in internalization of beta(2)-adrenergic receptors, Biochemistry 41 (2002) 10692-10699.

[8] Y.M. Kim, L.S. Barak, M.G. Caron, J.L. Benovic, Regulation of arrestin-3 phosphorylation by casein kinase II, J. Biol. Chem. 277 (2002) 16837-16846.

[9] S.K. Shenoy, L.S. Barak, K. Xiao, S. Ahn, M. Berthouze, A.K. Shukla, L.M. Luttrell, R.J. Lefkowitz, Ubiquitination of beta-arrestin links seven-transmembrane receptor endocytosis and ERK activation, J. Biol. Chem. 282 (2007) 29549-29562.

[10] S.K. Shenoy, P.H. McDonald, T.A. Kohout, R.J. Lefkowitz, Regulation of receptor fate by ubiquitination of activated beta 2-adrenergic receptor and beta-arrestin, Science 294 (2001) 1307-1313.

[11] H. Hayashi, D.T. Hess, R. Zhang, K. Sugi, H. Gao, B.L. Tan, D.E. Bowles, C.A. Milano, M.K. Jain, W.J. Koch, J.S. Stamler, S-Nitrosylation of beta-arrestins biases receptor signaling and confers ligand independence, Mol. Cell. 70 (2018) 473-487 e476.

[12] K. Ozawa, E.J. Whalen, C.D. Nelson, Y. Mu, D.T. Hess, R.J. Lefkowitz, J.S. Stamler, S-nitrosylation of beta-arrestin regulates beta-adrenergic receptor trafficking, Mol. Cell 31 (2008) 395-405.

[13] P.Y. Jean-Charles, N.J. Freedman, S.K. Shenoy, Chapter nine - cellular roles of betaarrestins as substrates and adaptors of ubiquitination and deubiquitination, Prog. Mol. Biol. Transl. Sci. 141 (2016) 339-369.

[14] S.K. Shenoy, R.J. Lefkowitz, Receptor-specific ubiquitination of beta-arrestin directs assembly and targeting of seven-transmembrane receptor signalosomes, J. Biol. Chem. 280 (2005) 15315-15324.

[15] D. Wyatt, R. Malik, A.C. Vesecky, A. Marchese, Small ubiquitin-like modifier modification of arrestin-3 regulates receptor trafficking, J. Biol. Chem. 286 (2011) 3884-3893.

[16] N. Xiao, H. Li, W. Mei, J. Cheng, SUMOylation attenuates human beta-arrestin 2 inhibition of IL-1R/TRAF6 signaling, J. Biol. Chem. 290 (2015) 1927-1935.

[17] H. Saitoh, R.T. Pu, M. Dasso, SUMO-1: wrestling with a new ubiquitin-related modifier, Trends Biochem. Sci. 22 (1997) 374-376.

[18] A. Pichler, C. Fatouros, H. Lee, N. Eisenhardt, SUMO conjugation - a mechanistic view, Biomol. Concepts 8 (2017) 13-36.

[19] M.J. Matunis, M.S. Rodriguez, Concepts and methodologies to study protein SUMOylation: an overview, Methods Mol. Biol. 1475 (2016) 3-22.

[20] E.T. Yeh, L. Gong, T. Kamitani, Ubiquitin-like proteins: new wines in new bottles, Gene 248 (2000) 1-14.

[21] F. Melchior, SUMO-nonclassical ubiquitin, Annu. Rev. Cell Dev. Biol. 16 (2000) 591-626.

[22] S.K. Shenoy, M.T. Drake, C.D. Nelson, D.A. Houtz, K. Xiao, S. Madabushi, E. Reiter, R.T. Premont, O. Lichtarge, R.J. Lefkowitz, Beta-arrestin-dependent, G protein-independent ERK1/2 activation by the beta2 adrenergic receptor, J. Biol. Chem. 281 (2006) 1261-1273.

[23] P.Y. Jean-Charles, L. Zhang, J.H. Wu, S.O. Han, L. Brian, N.J. Freedman, S.K. Shenoy, Ubiquitin-specific protease 20 regulates the reciprocal functions of beta-arrestin2 in toll-like receptor 4-promoted nuclear factor kappaB (NFkappaB) activation, J. Biol. Chem. 291 (2016) 7450-7464.

[24] F. Ayaydin, M. Dasso, Distinct in vivo dynamics of vertebrate SUMO paralogues, Mol. Biol. Cell 15 (2004) 5208-5218.

[25] M. Berthouze, V. Venkataramanan, Y. Li, S.K. Shenoy, The deubiquitinases USP33 and USP20 coordinate beta2 adrenergic receptor recycling and resensitization, EMBO J. 28 (2009) 1684-1696.
[26] K. Nagi, S.K. Shenoy, Detection of beta-arrestin-mediated G protein-coupled receptor ubiquitination using BRET, Methods Mol. Biol. 1957 (2019) 93-104.

[27] C. Gales, R.V. Rebois, M. Hogue, P. Trieu, A. Breit, T.E. Hebert, M. Bouvier, Realtime monitoring of receptor and G-protein interactions in living cells, Nat. Methods 2 (2005) 177-184.

[28] K. Nagi, I. Charfi, G. Pineyro, Kir3 channels undergo arrestin-dependant inter nalization following delta opioid receptor activation, Cell. mol. life sci. : CMLS 72 (2015) 3543-3557.

[29] N. Audet, G. Pineyro, Using BRET to detect ligand-specific conformational changes in preformed signalling complexes, Methods Mol. Biol. 756 (2011) 149-163.

[30] R.V. Rebois, M. Robitaille, C. Gales, D.J. Dupre, A. Baragli, P. Trieu, N. Ethier M. Bouvier, T.E. Hebert, Heterotrimeric G proteins form stable complexes with adenylyl cyclase and Kir3.1 channels in living cells, J. Cell Sci. 119 (2006) 2807-2818.

[31] M. Richard-Lalonde, K. Nagi, N. Audet, R. Sleno, M. Amraei, M. Hogue, G. Balboni, P.W. Schiller, M. Bouvier, T.E. Hebert, G. Pineyro, Conformational dynamics of Kir3.1/Kir3.2 channel activation via delta-opioid receptors, Mol. Pharmacol. 83 (2013) 416-428.

[32] F.F. Hamdan, Y. Percherancier, B. Breton, M. Bouvier, Monitoring protein-protein interactions in living cells by bioluminescence resonance energy transfer (BRET), Curr. Protoc. Neurosci. 5 (2006) 23 chapter 5, Unit.

[33] D.A. Sampson, M. Wang, M.J. Matunis, The small ubiquitin-like modifier-1 (SUMO 1) consensus sequence mediates Ubc9 binding and is essential for SUMO-1 modification, J. Biol. Chem. 276 (2001) 21664-21669.

[34] M.J. Matunis, J. Wu, G. Blobel, SUMO-1 modification and its role in targeting the ran GTPase-activating protein, RanGAP1, to the nuclear pore complex, J. Cell Biol. 140 (1998) 499-509.

[35] S.K. Shenoy, R.J. Lefkowitz, Trafficking patterns of beta-arrestin and G proteincoupled receptors determined by the kinetics of beta-arrestin deubiquitination, J. Biol. Chem. 278 (2003) 14498-14506.

[36] J.F. Mercier, A. Salahpour, S. Angers, A. Breit, M. Bouvier, Quantitative assessmen of beta 1- and beta 2-adrenergic receptor homo- and heterodimerization by bioluminescence resonance energy transfer, J. Biol. Chem. 277 (2002) 44925-44931.

[37] S.K. Shenoy, R.J. Lefkowitz, Receptor regulation: beta-arrestin moves up a notch, Nat. Cell Biol. 7 (2005) 1159-1161.

[38] J.M. Beaulieu, R.R. Gainetdinov, The physiology, signaling, and pharmacology of dopamine receptors, Pharmacol. Rev. 63 (2011) 182-217.

[39] D.R. Sibley, F.J. Monsma Jr., Molecular biology of dopamine receptors, Trends Pharmacol. Sci. 13 (1992) 61-69.

[40] S.M. Peterson, T.F. Pack, A.D. Wilkins, N.M. Urs, D.J. Urban, C.E. Bass, O. Lichtarge, M.G. Caron, Elucidation of G-protein and beta-arrestin functional selectivity at the dopamine D2 receptor, Proc. Natl. Acad. Sci. U. S. A. 112 (2015) 7097-7102.

[41] I. Erlenbach, J. Wess, Molecular basis of V2 vasopressin receptor/Gs coupling selectivity, J. Biol. Chem. 273 (1998) 26549-26558.

[42] A. Tohgo, E.W. Choy, D. Gesty-Palmer, K.L. Pierce, S. Laporte, R.H. Oakley, M.G. Caron, R.J. Lefkowitz, L.M. Luttrell, The stability of the G protein-coupled receptor-beta-arrestin interaction determines the mechanism and functional consequence of ERK activation, J. Biol. Chem. 278 (2003) 6258-6267.

[43] R.H. Oakley, S.A. Laporte, J.A. Holt, M.G. Caron, L.S. Barak, Differential affinities of visual arrestin, beta arrestin1, and beta arrestin2 for G protein-coupled receptors delineate two major classes of receptors, J. Biol. Chem. 275 (2000) 17201-17210.

[44] T.J. Cahill 3rdet al., Distinct conformations of GPCR-beta-arrestin complexes mediate desensitization, signaling, and endocytosis, Proc. Natl. Acad. Sci. U. S. A. 114 (2017) 2562-2567.

[45] T. Evron, S.M. Peterson, N.M. Urs, Y. Bai, L.K. Rochelle, M.G. Caron, L.S. Barak, G protein and beta-arrestin signaling bias at the ghrelin receptor, J. Biol. Chem. 289 (2014) 33442-33455.

[46] P.Y. Jean-Charles, V. Rajiv, S.K. Shenoy, Ubiquitin-related roles of beta-arrestins in endocytic trafficking and signal transduction, J. Cell. Physiol. 231 (2016) 2071-2080.

[47] K. Xiao, D.B. McClatchy, A.K. Shukla, Y. Zhao, M. Chen, S.K. Shenoy, J.R. Yates 3rd, R.J. Lefkowitz, Functional specialization of beta-arrestin interactions revealed by proteomic analysis, Proc. Natl. Acad. Sci. U. S. A. 104 (2007) 12011-12016.

[48] A. Werner, A. Flotho, F. Melchior, The RanBP2/RanGAP1*SUMO1/Ubc9 complex is multisubunit SUMO E3 ligase, Mol, Cell 46 (2012) 287-298.

[49] M.H. Lee, K.M. Appleton, E.G. Strungs, J.Y. Kwon, T.A. Morinelli, Y.K. Peterson, S.A. Laporte, L.M. Luttrell, The conformational signature of beta-arrestin2 predicts its trafficking and signalling functions, Nature 531 (2016) 665-668.

[50] S. Nuber, U. Zabel, K. Lorenz, A. Nuber, G. Milligan, A.B. Tobin, M.J. Lohse, C. Hoffmann, Beta-arrestin biosensors reveal a rapid, receptor-dependent activation/deactivation cycle, Nature 531 (2016) 661-664.

[51] F. Yang, X. Yu, C. Liu, C.X. Qu, Z. Gong, H.D. Liu, F.H. Li, H.M. Wang, D.F. He, F. Yi, C. Song, C.L. Tian, K.H. Xiao, J.Y. Wang, J.P. Sun, Phospho-selective mechanisms of arrestin conformations and functions revealed by unnatural amino acid in corporation and (19)F-NMR, Nat. Commun. 6 (2015) 8202.

[52] R.N. Freiman, R. Tjian, Regulating the regulators: lysine modifications make their mark, Cell 112 (2003) 11-17.

[53] D.C. Schwartz, M. Hochstrasser, A superfamily of protein tags: ubiquitin, SUMO and related modifiers, Trends Biochem. Sci. 28 (2003) 321-328.

[54] E.S. Johnson, Protein modification by SUMO, Annu. Rev. Biochem. 73 (2004) 355-382.

[55] A. Pichler, F. Melchior, Ubiquitin-related modifier SUMO1 and nucleocytoplasmic transport, Traffic 3 (2002) 381-387.

[56] Y.Y. Mo, Y. Yu, Z. Shen, W.T. Beck, Nucleolar delocalization of human topoisomerase I in response to topotecan correlates with sumoylation of the protein, J, Biol. Chem. 277 (2002) 2958-2964. 
[57] F.R. Bischoff, C. Klebe, J. Kretschmer, A. Wittinghofer, H. Ponstingl, RanGAP1 in duces GTPase activity of nuclear Ras-related ran, Proc. Natl. Acad. Sci. U. S. A. 9 (1994) 2587-2591.

[58] R. Mahajan, C. Delphin, T. Guan, L. Gerace, F. Melchior, A small ubiquitin-related polypeptide involved in targeting RanGAP1 to nuclear pore complex protein RanBP2, Cell 88 (1997) 97-107.

[59] T. Ritterhoff, H. Das, G. Hofhaus, R.R. Schroder, A. Flotho, F. Melchior, The RanBP2/RanGAP1*SUMO1/Ubc9 SUMO E3 ligase is a disassembly machine for Crm1-dependent nuclear export complexes, Nat. Commun. 7 (2016) 11482.

[60] K.A. McCrink, J. Maning, A. Vu, M. Jafferjee, C. Marrero, A. Brill, A. Bathgate-Siryk, S. Dabul, W.J. Koch, A. Lymperopoulos, Beta-Arrestin2 improves post-myocardial infarction heart failure via Sarco(endo)plasmic reticulum ca(2+)-ATPase- dependent positive inotropy in cardiomyocytes, Hypertension 70 (2017) 972-981.

[61] J. Zhang, Y. Liu, K. Jiang, J. Jia, SUMO regulates the activity of smoothened and Costal-2 in drosophila hedgehog signaling, Sci. Rep. 7 (2017) 42749.

[62] R.H. Oakley, S.A. Laporte, J.A. Holt, L.S. Barak, M.G. Caron, Molecular determinants underlying the formation of stable intracellular $\mathrm{G}$ protein-coupled receptorbeta-arrestin complexes after receptor endocytosis*, J. Biol. Chem. 276 (2001) 19452-19460.

[63] J.D. Wright, P.D. Mace, C.L. Day, Noncovalent ubiquitin interactions regulate the catalytic activity of ubiquitin writers, Trends Biochem. Sci 41 (2016) 924-937.

[64] O. Kerscher, SUMO junction-what's your function? new insights through SUMOinteracting motifs, EMBO Rep. 8 (2007) 550-555. 